\title{
Ses Bilgisi Açısından Karakalpak Türkçesindeki Birincil ve İkincil Yansıma Kelimeler
}

\section{Primary and Secondary Onomatopoeic Words in Karakalpak Turkish in Terms of Phonics}

\author{
Dilek Kaplankıran ${ }^{1,2}$ (1)
}

'Öğretim Görevlisi, İstanbul Aydın Üniversitesi, TÖMER, İstanbul, Türkiye

${ }^{2}$ Doktora öğrencisi, Erciyes Üniversitesi, Sosyal Bilimler Enstitüsü, Türk Dili ve Edebiyatı Bölümü, Kayseri, Türkiye

ORCID: D.K. 0000-0001-7367-7723

Sorumlu yazar/Corresponding author: Dilek Kaplankıran,

İstanbul Aydın Üniversitesi, TÖMER, İstanbul, Türkiye

E-mail: dilekkaplankiran@hotmail.com

Başvuru/Submitted: 21.03.2021

Revizyon Talebi/Revision Requested: 09.04.202 Son Revizyon/Last Revision Received: 14.04.2021 Kabul/Accepted: 08.06 .2021

\section{Atıf/Citation:}

Kaplankiran, D. (2021). Ses bilgisi açısından Karakalpak Türkçesindeki birincil ve ikincil yansıma kelimeler. TUDED, 61(1), 177-203. https://doi.org/10.26650/TUDED2021-900760

\section{ÖZET}

Yansıma kelimeler dilde önemli bir yere sahiptir. İnsan, hayvan ve nesnelerin istemli veya istemsiz çıkardıkları sesleri ya da onların davranış ile hareketlerini ifade etmek için kullanılan sözcüklere yansıma kelimeler denilmektedir. Bu sözcükler bir sesi ya da hareketi betimlemektedir. Yansımalar ses ve hece sayısına göre birincil ve ikincil olarak ikiye ayrılmaktadır. Birincil yansımalar tek heceli, ikincil yansımalar ise çok heceli sözcükleri temsil eder. Yansıma kelimeler aracılığı ile anlatılmak istenen hareket, ses veya görünüş daha net ve açık bir şekilde anlatılmakta ve içinde bulunulan durum ya da olay resmedilerek canlandırılmaktadır.

Karakalpak Türkçesinde "yeliklewişler" adıyla geçen yansıma kelimeler "seske yeliklewișler" ve "köriniske yeliklewișler" olmak üzere ikiye ayrılır ve söz varlığı açısından oldukça zengindir. Yansımalarda, sözcüğün ifade ettiği özellik ile bulundurduğu sesler arasında bir ilișki olduğu düșünülmektedir. Seslerin kelimelere kattığı anlamlar ve çeşitli etkiler bu çalışma ile gösterilmeye çalışılmıștır. Çalışmada Karakalpak Türkçesi sözlüğü taranarak yansıma yoluyla oluşturulan söz varlığı ortaya çıkarılmış ve yansıma kökler üzerinden fonetik bir inceleme yapılmıştır. Yansıma köklerde çeşitli seslerin kullanılarak bazı anlamları kattığı ve belirli bir ses sisteminin var olduğu görülmüştür. Türk lehçe ve şivelerinde sayıca oldukça fazla ve yoğun bir şekilde kullanılan yansıma kelimeler, pek çok açıdan ele alınması gereken mühim bir konudur.

Anahtar Kelimeler: Yansıma kelimeler, yeliklewişler, onomatope, Karakalpak Türkçesi, birincil ve ikincil yansımalar

\section{ABSTRACT}

Onomatopoeic words occupy a crucial position in language. They are words used to express voluntary or involuntary human and animal sounds as well as those of objects or their behaviors and/or movements. Briefly, such words identify sounds or movements. Onomatopoeic words can be classified as either primary or secondary based on their number of sounds and syllables. Primary onomatopoeics represent one-syllable words, and secondary onomatopoeics represent multisyllable words. The movement, sound or appearance, which are intended to be explained with reflection words, are explained more clearly and the current stuation is illustrated and animated. Onomatopoeic words in Karakalpak Turkish, which are called "yeliklewişler," can be classified as either "seske yeliklewişler" or "köriniske yeliklewişler," and are rich in vocabulary. In onomatopoeics, a relationship exists between the feature a word expresses and the sound it makes. This study attempts to reveal the meaning that sounds contribute to words and the former's effects on the latter. For this study, the Karakalpak Turkish dictionary is scanned, and vocabulary words that are onomatopoeic are revealed. Moreover, a phonetic examination of onomatopoeic roots is conducted. Through onomatopoeic roots, various sounds can be seen as contributing meaning to as well as the existence of a significant sound system. Onomatopoeic words, which are used heavily in Turkish dialects and accents, are an important subject that should be discussed from various perspectives.

Keywords: Karakalpak Turkish, onomatopoeia, onomatopoeic words, primary and secondary onomatopoeics, yeliklewişler 


\section{EXTENDED ABSTRACT}

Onomatopoeic words are formed through the imitation of sounds in nature and demonstration of various movements, and have an important place and extensive usage in language. Onomatopoeic words breathe new life into languages and are common in colloquial language. Moreover, onomatopoeic words are shaped according to each language's rules and share similarities with different languages. Especially those words produced through sound imitation can share similarities or demonstrate differences with other languages.

The term yeliklewişler is used in Karakalpak Turkish and can be divided in two based on its meaning, that is, seske yeliktewişler or "sound imitation" and köriniske yeliktewişler or "appearance imitation." Sound imitations include human, animal, bird, and object movement sounds, and representative examples include tars tars, şırt şırt, and mırs mırs. Sound imitations can further be divided into two groups, that is, imitations of living creatures and imitations of lifeless objects. Sounds from humans, animals, and children represent the imitation of living creatures, whereas sounds from the surroundings and the natural sounds resulting from movements represent the imitation of lifeless creatures. Meanwhile, appearance imitation includes onomatopoeic words based on the movements of living creatures or objects, and representative examples include pırrım pırrım, jılt jılt, and dă̆al dă̆al.

This study analyzes and reveals the sound features of onomatopoeic words in general terms and demonstrates that onomatopoeic words have a broad and special place in Karakalpak Turkish. While the solo usages of onomatopoeic roots, which are primary forms, are uncommon, extensive shapes generated from onomatopoeic roots, which are secondary forms, are more common. In onomatopoeics, primary and secondary shapes are used in sentences by taking and expanding auxiliary verbs with derivational affixes or forming reduplications, such as birq-birq et-, birqulda-, and so on.

By examining onomatopoeic words in Karakalpak Turkish, we see that vowels differ and are unstable. Semantic differences also reveal changes in vowels. For instance, bajllda- means "yelling in anger; saying bad words," whereas bijllda- means "talking too much; grumbling." While the first example expresses a thick, rude, and loud sound, the second example does not represent a loud sound. Extending such examples is also possible. For example, manquldaq means "chatterer; someone blabbing; tactless," whereas mıyqulda means "nasal twang; blithering; and so on." Varieties in vowels in onomatopoeics contribute meanings such as strong weak, violent non-violent, continuous discontinuous, and intense mild. In terms of the sounds they reflect, wide vowels have stronger sounds than narrow vowels, whereas narrow vowels have weaker and more unclear sounds than wide vowels. For example, qorqulda- means "slurping a liquid," and the sound it indicates is rude and intense, whereas qulqulda-, which means "drinking a liquid noisily," is similar to "chugging" and represents the natural sound produced while drinking, rather than a rude or loud sound. Sound and meaning relationships exist between onomatopoeic words, which form a vocabulary via their unique sounds and syllable system. 
Onomatopoeic words form through the emergence of one, two, three, four, five, or six sounds in terms of sound number, and primary shapes form in terms of vowels and consonants, such as $\mathrm{V}, \mathrm{CV}, \mathrm{VC}, \mathrm{CVC}, \mathrm{VVC}$, and CVCC. Moreover, secondary shapes are VCVC, VCCV, VCCVC, CVCVC, and CVCCVC. Among these structures, CVC and CVCC are the most common.

Karakalpak Turkish discriminates between the meanings of some sounds at the onset, peak, and coda of onomatopoeic words. Onomatopoeics abide by the general phonetic rules of Turkish and Karakalpak Turkish in terms of onset or coda vowels.

The usage of significant structures and sounds in the coda of onomatopoeic words can be observed through phonetic examination. Consonants b, d, g/ /g, j, k/q, l, m, p, s, ş, t, w, and z can be seen at the onset of onomatopoeic words in Karakalpak Turkish. While checking the consonants used in the coda (CV), b/p, k/q, l, $\mathrm{y}, \mathrm{r}, \mathrm{s}, \mathrm{w}$, and $\mathrm{z}$ sounds are considered as primary shapes with two sounds, while in (CVC), b/p, g/ $\breve{g}, \mathrm{j}, \mathrm{k} / \mathrm{q}, \mathrm{l}, \mathrm{m}, \mathrm{y}, \mathrm{r}, \mathrm{s}, \mathrm{s}, \mathrm{t}, \mathrm{w}$, and z sounds are deemed as primary shapes with three sounds. A total of 12 dual consonants can be seen in the coda of primary-shaped (CVCC) structured onomatopoeic words. Dual structures are

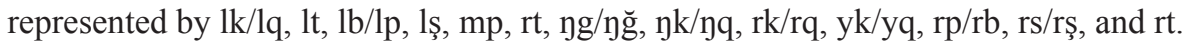

Primary shapes generally form secondary shapes by enlarging -ir or -il. In some examples,

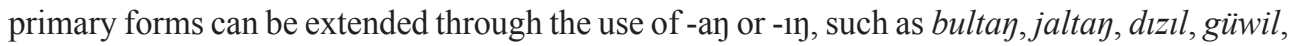

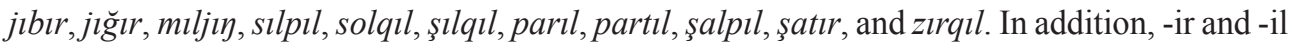
contribute significant meanings while enlarging onomatopoeic words. Specifically, each structure contributes the meaning of "being durable-being not durable" and "continuity-discontinuity," such as digirle-, which means "something rattling in crooked place; making a sound," and dikilde-, which means "heart pounding frequently and strongly; thumping violently." The first example represents an intermittent, distant sound with no contact to a smooth surface, whereas the second example represents a continuous, nonstop sound. 


\section{GİRIŞ}

Ses ve hareketlerin taklit ve tasvir edilmesi sonucu ortaya çıkan yansıma kelimeler, Türkçede söz varlığı açısından önemli bir yere ve geniş kullanıma sahiptir. Yansıma kelimelerin kullanımı dile canlılık katmakta ve özellikle konuşma dilinde yaygın olarak kullanılmaktadır. Yansıma kelimeler her dilin kurallarına göre şekil alabildiği gibi farklı dillerde benzerlik gösterebilmektedir. Özellikle ses taklidi yoluyla oluşan yansıma kelimeler bazı dillerde benzer şekillerde, bazı dillerde ise farklı kullanımlarla karşımıza çıkabilmektedir. Yansıma kelimeler doğadaki seslerin taklit ve çeşitli hareketlerin tasvir edilmesi yoluyla oluşmaktadır.

Doğadaki sesler ifade edilirken insanların duyum eşiğine göre sesler taklit edilmektedir. Örneğin, Türkçede horozun çıkardığı ses “ ̈й ü-rüü üüü” şeklinde taklit edilirken farklı dillerde horoz sesi için çeşitli kullanımlar görülebilmektedir. Almanca "kıkerik"; Moğolca "o uu" (Karahan, 2011: 1); Fransızca, "coqoerico"; İngilizce "cock-a-doodle-doo" (Balkaya, 1999: 9); Rusça "kukeriku” (Gültek, 2012: 567) şeklinde taklit edilen horoz sesi aslında aynı sestir, ancak her dilde farklı şekillerde yansıtılmaktadır. Aynı şekilde ağaç kırıldığında dünyanın her yerinde kırılma şekline ve şiddetine bağlı olarak benzer sesler çıkmaktadır ancak dillerde sesin algılanma biçimi farklılıkları doğurmaktadır. Hayvan sesleri, genellikle dilde ses birliği olarak kabul edilmekte ve yansıma kelimeler arasında dilin özelliklerini taşıyan bir birim olarak değerlendirilmemektedir.

"Doğadaki sesler özellikle de hayvanların çıkardığı sesler, ses kaynaklarına gelmez, onlarda fonem yoktur, ayrılmaz ses birlikleri vardır. Genellikle de bunlar çok anlamlı (polisemantique) olur ve serbest olguların sonucudur. Ses yansıması sözlerin yapısı ve kullanımı tamamen başka bir karakter taşır, sesin yapısına göre ya telaffuzu hazırlayan süreç veya telaffuzun kendi adı bildirilir" (Serebrennikov ve Gadjieva, 2018:207).

Yansımalar üzerine yapılan çok sayıda çalışma bulunmaktadır. "Dilsel bir işaret olan 'sözcük' ile kavramlar arasındaki ilişki, dile dair ilk felsefi tartışmalardan başlayarak modern dil biliminin de önemli meselelerinden biri olmuş; bu hususta yansımaların durumu her zaman dikkatleri çekmiştir” (Özbek, 2019: 11-12). Türkiye Türkçesinde yansımalarla ilgili en kapsamlı çalışma Hamza Zülfikar (1996) tarafından "Türkçede Ses Yansımalı Kelimeler” adıyla hazırlanmış ve detaylı bir inceleme yapılarak yansıma kelimelerin söz varlığı ortaya çıkarılmıştır. Omuralieva (2019) ise yansıma kelimelerle ilgili Türkiye'de ve yurt dışında yapılan çalışmaları tespit etmiş, “Yansıma Kelimeler Üzerine Bir Bibliyografya Denemesi” adlı çalışmayı hazırlamıştır.

Türkiye Türkçesinde yansıma kelimeler için çeşitli terimlerin kullanıldığı görülmektedir. Zülfikar, bu alanda kullanılan ilk terimin "onomatopoeia" olduğunu ve Osmanlıcada "lafztaklidi" ve "savt-l taklidi" şeklinde geçen terimin, zamanla "taklidi kelimeler" şeklinde kullanılmaya başlandığını belirtir (1995:2). Ayrıca Türkçede onomatope için "yansıma, yansılama, yansitan kelime, yankı kelime, yankılık, tabiat taklidi kelime, ses taklidi, taklidi nida, ses ad" terimlerinin kullanıldığı ve konunun ikilemeler ile ünlemler içinde ele alındığı ifade edilmektedir (Zülfikar, 1995:5). 
Naskali ise yansıma kelimeler için “Türk Dünyası Gramer Terimleri Kılavuzu”nda şu şekilde karş11ıklarını vermektedir: Az.: täğlidi sözlär, Tkm.: ses meyzetmesi, Gag.: onomatopeyik laflar r yansilamalar onomatopeya, Özb.: taqlidiy soz, Uyg.: täqlidiy söz, Tat.: awaz iyärteme, Bşk.: okşatıw hüzzäre, Kmk.: predmetleni awazların wa tawuşların ạlatagan söz, Krç.-Malk.: eriklewçü söz eniklewçü söz, Nog.: erkelew söz, Kaz.: eliktewiş söz, Krg.: tuurandı söz, Alt.: ötkönişs sös, Hks.: köögîs sös, Tuv.: öttünüg söz, Şor.: köögüs sös, Rus.: zvukopodrajatelnoye slovo" (Naskali, 1997: 77).

Bir dilde yansıma kelimelerin tespiti kolay değildir, bu nedenle yansımanın ne demek olduğu iyi anlaşılmalıdır. Yansıma kelimeler, hareketlerin betimlenmesi ve duyulan seslerin taklit edilmesi sonucunda dil özelliklerine göre görünüşlerin ve seslerin şekil alması olarak ifade edilebilir. Çağatay, yansımalardan "onomatopee, yani tabiî sesleri taklit eden teşkiller" şeklinde bahsetmektedir (1978: 34). Vardar, yansıma kelimeleri, "dış gerçeklik düzleminde var olan ses ya da gürültüleri, işitimsel izlenimi yansıtacak biçimde aktaran, adlandırılan gerçeği ses öykünmesi yoluyla belirten dilsel öğe (pat, şak, tık, vb.) ” şeklinde açıklamaktadır (1988: 224-225). Banguoğlu, yansilama terimini kullanarak "tabiat seslerini tasvir veya kabataslak taklit ederek meydana gelmiş ses topluluklarl” şeklinde tanımlar. Ayrıca seslerin andırdığı nesne veya hareket anlamını taşıyan yansımaların, ünlemlere en çok yaklaşan kelime türü olduğunu belirtir (2007:402). Atabay, Kutluk ve Özel, yansımayı “doğa seslerinin söz şeklinde biçimlenişi” olarak tanımlar ve diğer sözcüklerden farklı olan yansımalarda nesne ve ad ilişkisinin var olduğunu ifade eder (1983:37). Janjua, benzetme ve taklit sözcükleri, dili dil yapan özellik olarak belirtmekte ve konuşmanın özünü oluşturan unsur olarak nitelendirmektedir. Ayrıca, yansımaların çıkış noktasının insan duyguları olduğuna dikkat çekmektedir (2000: 7). Sis ve Gökçe, yansımaları “doğadaki varlıkların ya da çeşitli nesnelerin çıkardı̆̆ seslerin öykünülmesi yoluyla oluşmuş sözcüklerdir" şeklinde tanımlamakta ve "dilcilikte yansıma adını alan ve doğadaki sesleri canlandıran öğeler içinden, bu türdeki örneklerin Türkçedeki çeşitliliğine ve işlekliğine başka dillerde rastlamanın güç” olduğuna dikkat çekmektedir (2009: 1976).

Bazı yansımaları tespit etmek çok kolaydır. Örneğin, "tak tak, tıkırtı, çıtırtı, güm” gibi sözcüklere bakıldığında kelimelerin yansıma kökenli olduğu hemen fark edilebilir. Fakat dildeki morfolojik özellikleri üzerine alarak isim ya da fiil şeklinde kullanılan yansıma kelimeleri tespit etmek güçleşmektedir. Bu durumda dilin fonetik ve morfolojik özelliklerinin iyi bilinmesi gerekir. Kelimelerin tespiti konusunda dikkatli olunmalı ve ekler ayrılarak yansıma köklere ulaşılmalıdır. Ancak bazen ulaşılan her kök Balkaya'nın belirttiği gibi yansıma sözcüklerle aynı sesleri taşıyor olsa bile yansıma olarak kabul edilemez. Örneğin " $s s l ı k$ " yansıma kökenli bir isimdir. Islık kelimesi yansıma kökenli olduğu için " $l s$ ” köküyle türetilen bütün sözcükleri yansıma olarak değerlendiremeyiz. "Islanmak, 1sınmak, 1sı, 1slak" gibi kelimeler, içinde aynı sesi barındırmasına rağmen farklı köklerden oluşan sözcüklerdir (1996: 24). Bu bağlamda yansıma kökenli kelimelerin tespiti büyük bir titizlik gerektirmektedir.

Karakalpak Türkçesinde yansıma kelimeler için yeliklewişler terimi kullanılmakta ve yeliklewişler anlam özellikleri açısından ikiye ayrılmaktadır. Birincisi seske yeliktewişler 
“ses taklitleri”, ikincisi ise köriniske yeliktewişler "görünüş taklitleri” ş̧eklindedir. Ses taklitleri; insan, hayvan, kuş ve nesne hareketlerinin taklidi sonucu ortaya çıkar ve tars tars "takır tukur", şırt şırt "çıt çıt”, mırs mırs "kıs kıs (gülmek)” gibi örnekleri temsil eder. Ses taklitleri de kendi içerisinde canlıların ve cansız nesnelerin taklitleri olmak üzere iki grupta ele alınır. İnsan, hayvan, çocuk vb. varlıkların çıkarmış olduğu sesler canlı varlıkların taklidi; doğadaki varlık ve çevremizdeki her şeyin, hareketler sonucunda çıkarmış oldukları sesler ise cansız varlıkların taklidini temsil etmektedir. Görünüş taklitleri ise canlıların ya da nesnelerin hareketleri sonucunda ortaya çıkan yansıma kelimelerdir. Pırrım pırrım "parça parça", jult jılt "1şıl 1şıl", dăgal dăgal "haldır huldur (kaba)" gibi örnekleri kapsamaktadır (Seytnazarova, 2006: 32).

Yansıma kelimeler için Kazak Türkçesinde "yeliktew sözder" ve "yelikteme" terimleri kullanılmakta ve yeliktewiş ve beynelewiş olmak üzere iki grupta yansımalar ele alınmaktadır. Beynelewiş sözder; doğanın, insanların, hayvanların ya da cansız varlıkların hareketlerini ifade ederken yeliktewiş sözder, ses taklidi ile oluşan yansımaları temsil etmekte; canlı ve cansız varlıkların çıkardığı sesleri ifade etmektedir (Iskakov, 1991: 344-345; Karakaş, 2013; Biray, 2014:1092). Kırgız Türkçesinde ise "tuurandı sözdör" adıyla geçmekte ve ikiye ayrılmaktadır. "tabış tuurandı sözdör", ses yansımalı kelimeler; "eles tuurandı sözdör” ise görüntünün tasvirine dayalı olan yansımalardır (Tazhieva, 2020: 11). Şınnazarova ve Aljanova, doğadaki her türlü olgunun sanatsal, etkili ve mecazi olarak tanımlanması için yansımalara başvurmak gerektiğini belirtir. Ayrıca yansımaların sözcüksel anlamlarının olmadığını ancak kendine özgü ses özelliklerinin bulunduğunu ifade etmektedir (2019: 27).

\section{Ses Özellikleri Açısından Yansıma Kelimeler}

Yansıma kelimeler çeşitli yollarla oluşmaktadır. Zülfikar (1995: 92-101-106), tek heceli yansımaları "birincil biçimler"; birincil biçimlerden oluşan yapıları ise "ikincil biçimler"; ikincil biçimlerin, yapım ekleri aracılığı ile türetilen şekillerini ise "türev” adıyla ele almaktadır. Banguoğlu, tek heceli biçimlerin -1r ve -1l ile uzatılması sonucunda ikincil biçimlerin elde edildiğini ifade etmekte ve yansımaları "basit ve uzatılmış kök kelimeler" şeklinde sınıflandırmaktadır (2007: 404-407). Korkmaz, ses yansımalı kökleri birincil biçimler (çat, güm, küt) ve birincil biçimlerin genişletilmesi yoluyla oluşturulan ikincil biçimler şeklinde ayırmaktadır (gür-ül, çat-ır, şak-1r) (2009: 1187). "Kelimenin kökü ana dilin bize hediye ettiği bir mana unsurudur. Onun bu bakımdan bir hayatiyeti ve başlı başına bir tekâmül tarihi vardır." diyen Banguoğlu kökler üzerine dikkat çekmektedir (1941:32).

Korkmaz, -Ir ve -Il ile oluşturulan ikincil biçimler için şu açıklamayı yapmaktadır:

"Bunlar her ne kadar bir türemiş kelime görünümünde iseler de bu türeme asıl kelime türetimine temel oluşturan birer ses genişlemesinden ibarettir. Seslerin türetme eklerindeki gibi birer işlevi yoktur. Bu nedenle, ses genişlemesine uğramış yansımalı sözler de birer yalın ad niteliğindedir. Ancak kendine özgü farklı bir tür oluşturmaktadır" (2009: 222). 
Türkçede olduğu gibi Karakalpak Türkçesinde yansımalardan türetilen biçimlere sıkça rastlanırken kök hâlinde bulunan yansımalar tek başlarına genellikle tanıklanamamaktadır. Yansıma kökler yanlarına "jalp et-” örneğinde olduğu gibi bir yardımcı fiil alarak veya çeşitli yapım ekleriyle türetilerek ya da tekrarlanarak ikileme şeklinde kullanılmaktadır (11)-jı̄j; jılbıra-; ınqılda- vb.). "pırla-" örneğini ele aldığımızda "-la" burada bir yapım ekidir, "pır” yansıma köktür. Tek başına kullanımı mevcut kaynaklarda tanıklanamamış olsa da yansıma olarak ele alınması gereken kısım "pır" yani kök kısmıdır. Bu kapsamda çalışmanın konusunu yansıma kökler oluşturmakta ve yansımalarda kullanılan ekler konunun kapsamına girmemektedir.

Yansımalarda, sözcüğün ifade ettiği özellik ile bünyesinde bulundurduğu sesler arasında bir ilişki olduğu düşünülmektedir. Geniş ya da dar olma özelliğine göre seslerin kelimelere etkisiyle ilgili olarak Zülfikar, "birincil biçimlerde genişs ünlü şiddeti, kuvveti, yoğunluğu, kalınlığı, büyüklüğ̈̈ ve zengin katılmalarl, dar ünlü ise bu özelliklerin daha zaylf olduğunu temsil etmektedir" der (1995: 25). Mesela çat, çıt, çut ya da tak, tuk, tok gibi seslerin tanımı yapılırken sesin, ince-sert; şiddetli-şiddetsiz; yoğun-hafif olma durumlarının belirtilmesi gerektiğini ifade eder. Çünkü görülmektedir ki her ünlü, taşıdığı özelliği yansıma kelimeye aktarmaktadır. Ay, "Yansıma sözcüklerle ifade edilen dil dışı sesin/görüngünün sürekli, kesikli, yinelemeli, düzenli, şiddetli ve daha başka özelliklere sahip oluşu, ses birimlerinin temsil ettiği anlam yükleriyle ifade edilir." demektedir (2020: 559).

Ses yansımalarında özellikle birincil biçimlerin doğadaki seslerle ilgisi bulunmaktadır. Çıkan sesin durumunu, şiddetini ifade etmede belirli anlam ilişkilerine rastlanılmaktadır.

Birincil biçimlerin ünlüsü kalın, geniş, düz (a) ya da kalın, geniş, yuvarlak (o) seslerinden biri ise yansıttığı hareketlerin güçlü, şiddetli, sürekli, zorlu ve harekete katılmaların çok yönlü olduğunu bildirmektedir. Birincil biçimlerdeki hecenin ünlüsü ince, düz, dar (i) ya da kalın, dar, düz (1) ise yansıttığı hareket, güçsüz, şiddetsiz, süreksiz ve hafif olup frekansı da düşüktür. (Zülfikar, 1995: 25).

Örneğin Türkçede "tık tık" daha zayıf bir sesi ifade ederken, "tak tak" daha kaba ve şiddetli bir sesi ifade etmektedir.

Baytok, Kırgız Türkçesinde ikileme şeklindeki yansımalarda düz ve yuvarlak ünlüler arasında ayrımların olduğunu belirtir ve "eğer ikilemenin her iki öğesi de aynı, yani düz ünlüye sahipse sesin aynı şekilde duyulduğunu; ikilemenin ilk öğesi düz ünlüye, ikinci öğesi yuvarlak ünlüye sahipse sesin düzensiz, gelişigüzel olduğunu bildirir” demektedir (2014: 121).

Aksan, “dilin sözcüklerinin genellikle birer soyutlama ürünü olduklarını, nesneyle sözcük arasında ses açısından bir uygunluk bulunmadı̆̆ını" ifade etmekte ve diğer görüşlerin aksine ses ile sözcük arasında bir ilişki bulunmadığını belirtmektedir (2009: 96).

Biray, yansımaların; ses, vurgu, sesin ahengi, hız ve ritim çeşitliliği açısından ünlemler gibi değişkenlik gösterdiğini ve taklit edilen ses ya da hareketin hızlı-yavaş, yavaş-sert, kısa-uzun, 
yalın-karmaşık olmasına bağlı olarak bazen yavaş bazen sürekli bazen de çekip alırcasına hızlı, tez ya da kısa vurguyla söylendiğini ve çeşitlendiğini belirtir (2014: 1093).

Karakalpak Türkçesinde ünlüler açısından yansıma kelimeleri ele aldığımızda Türkiye Türkçesindeki gibi ünlülerin değişkenlik gösterdiğini görmekteyiz. Örneğin, partla- "patlayarak ses çıkarmak, yarılmak" anlamında şiddetli bir sesi anlatmaktadır. pırt et- "sıvının/suyun birdenbire sıçraması" ise çok şiddetli olmayan bir sıçrama sesini ifade etmektedir. Türkiye Türkçesinde olduğu gibi Karakalpak Türkçesinde de birincil biçimlerde ünlü seslerin değişkenlik göstermesi anlama güçlü-güçsüz, şiddetli-şiddetsiz, sürekli-süreksiz, yoğun-hafif gibi anlamlar katmaktadır. Gülmeyi anlatan yasıma kelimelerden, larqılda- "yüksek sesle gülmek, kahkaha atmak" (KTS 368); mırs mırs etip kül- "kıs kıs gülmek, hafifçe ve zor duyulur tarzda gülmek" (KTS 395) anlamlarını taşımaktadır. Bu örnekte bu durumu kanıtlar niteliktedir.

Gencan, ünlü ve ünsüzleri şu bakımdan ayırmaktadır. "Ünlüler sestir, ağızdan bir engele uğramamış gibi serbestçe çıkarlar." Ünsüzler ise "ses yolunda az çok engele uğrayıp biçimlenerek boğumlanarak çıkarlar" (2001: 55). Ergin, Türkçe kelimelerin sonunda kullanılabilecek çift ünsüzleri örneklerle göstermekte ve yansımalarda dahi bu çift ünsüzler dışında başka bir çift ünsüz yapısının bulunamayacağını belirtmektedir. Bunlar: lç, lk, lp, lt, nç, nk, nt, rç, rk, rp, rs, rt, st, şt (2019: 86). Deny, Türkçedeki ünsüz diftongları ele aldığı kısımda, 12 kombin bulunduğunu ve diftonglardaki ilk ünsüzün akıcı ünsüzler $(r, 1, n)$, ikinci ünsüzün ise patlayıcı tonsuz ünsüzler (p, t, ç, k) olduğunu belirtir: rp, rt, rk, lp, lt, lç, lk, np, mb, nt, nç, nk (1995: 83). Kazak ve Kırgız Türkçesi yansıma kelimelerde birincil biçimlerin sonunda benzer çift ünsüzlerin kullanımı yaygın olarak yapılan çalışmalarda görülmektedir (Karakaş, 2013; Baytok, 2014: 118). Yansımaların oluşmasında ünlüler ve ünsüzler önem taşımaktadır.

\section{Yansıma Kökler Üzerine İnceleme}

\subsection{Yansıma Kelimelerde Hece ve Ses Yapısı}

Karakalpak Türkçesi söz varlığında tespiti yapılan yansıma kelimeler, bu bölümde değerlendirilerek gruplandırılmaktadır. Yansımalarda -ır ve -1l ile uzatılan yapılar çokça görülmektedir. Yansımaların hem uzatılmış şekilleri hem de en küçük kök birimleri bu çalışmayla ele alınmaktadır. Uzatılan şekilleriyle kullanılan yapılar bölünerek en küçük yansıma kökler hâlinde bu çalışmada değerlendirilmiştir. Örneğin "sanqılda-" kelimesi fiil şekliyle tanıklanırken "sāq" kullanımı tanıklanamamıştır. Ancak görüyoruz ki buradaki yansıma kök birim "sạq" şeklidir. Bu nedenle örnek teşkil etmese de kök birimler üzerine değerlendirmeler yapmak gerekmektedir. Bu bağlamda yansımalar hece, ses sayıları ve seslerin kullanımı bakımından bu bölümde ele alınmaktadır.

\subsubsection{Tek Sesten Oluşanlar}

Tek ünlü ile oluşurlar (V): a, ö, u. Tek sesten oluşmakta ve üç örneğe rastlanmaktadır. Burada geçen ilk örnek, kurt ve köpek sesi için kullanılan $u l$ - fiilindeki "uu” sesi; ikincisi 
aqır- "haykırmak, bağırmak" anlamında kullanılan fiildeki "aa” sesi; üçüncü ise ökir- "yüksek sesle ağlamak” fiilindeki “öö” sesidir.

\subsection{2. İki Sesten Oluşanlar}

İki sesin yan yana gelmesi sonucu oluşmakta ve iki şekilde görülmektedir.

2.1.2.1. Bir ünsüz bir ünlü ile oluşanlar (CV): Burada "mee" ve "möö” gibi hayvan sesleri, “tüü (tükir-); kee (kekir-); qaa (qaqır-)” gibi ağızdan çıkan sesler ve "ğağırla-” sözcüğündeki “ğa” sesi yer almaktadır.2.1.2.2. Bir ünlü bir ünsüz ile oluşanlar (VC): ab, al, ay, ap, äw, ib, ay, 11, 1r, 1s, 1z, uw.

\subsection{3. Üç Sesten Oluşanlar}

Üç sesten oluşan yansıma seslerdir ve çoğunlukla (CVC) yapısının örnekleri yer almaktadır.

2.1.3.1. ünsüz-ünlü-ünsüz ile oluşanlar (CVC): Bu gruptaki kök birimlerin ilk sesleri $b, d$,

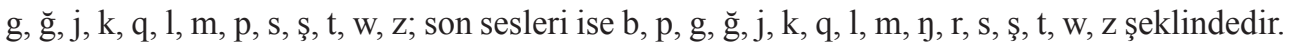
Ör: baj, baq, bez, bıd, bıj, bır, bıt, dar, dır, dız, dig/dik, dir, duw, düb/düp, dük, dür, düs, gib, guw, güb, güm, güy, gür, güw, ğıj, ğış, ğuj, ğur, jab, jıb, jığg, jım, juğ, kis, kiş, qay, q1r, q1t, qor, qur, lap, laq, lıp, lıq, lüp, mạ, mıj, mır, par, pat, pır, pıs, pış, pıt, pır, saq, sat, sıb/sıp, sır, sim, şaq, şat, şıj, şıq, şı1t, şuw, täk, taq, tas, tıp, tıq, toq, waj, zaq, zım, zıı, zır, zuw.

2.1.3.2. ünlü-ünsüz-ünsüz ile oluşanlar (VCC): Bu gruptaki kelimelerin bazılarının buradaki gibi yalın kök hâlleriyle kullanımı tanıklanamamaktadır ancak görülmektedir ki bu yapılar, -1r ve -1l ile uzatılan yansıma kelimelerin kök birimlerini teşkil eder. Bu nedenle ayrı bir kategoride gösterilmektedir. Ör: ars, äwk, äwp, elp, enk, ı๊q, 1rj, 1rs, ing, uyp.

\subsubsection{Dört Sesten Oluşanlar}

2.1.4.1. ünlü-ünsüz-ünlü-ünsüz ile oluşanlar (VCVC): Bu gruptaki örnekler iki sesten oluşan kök birimlerin -ır, -11, ın ile uzatılması sonucu oluşmaktadır: abır, adır, apıl, apır, äwil,

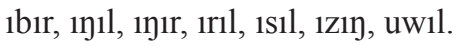

2.1.4.2. ünlü-ünsüz-ünsüz-ünlü ile oluşanlar (VCCV): Bu gruptaki örnekler sadece ikilemelerden oluşur ve ikinci kelime birincinin önüne bir ünsüz ses getirilerek oluşturulur. Ör: alba-julba, alba-dulba, uypa-juypa, alba-dalba, uypa-juypa. Örneklere bakıldığında dört sesli yansıma kelimenin önüne $d$ ve $\mathrm{j}$ sesleri getirilerek ikilemenin ikinci kısmının oluşturulduğu görülmektedir.

2.1.4.3. ünsüz-ünlü-ünsüz-ünsüz ile oluşanlar (CVCC): Bu gruptaki kelimelerin üçüncü sesi akıcı ünsüzlerden (l, m, n, r, y) oluşmaktadır. Son seste ise b/p, g/ ̆g, k/q, s, ş, t sesleri yer almakta ve yansıma köklerin sonunda şu ikili yapılar görülmektedir: lk/lq; lt; lb/lp; 1ş; mp; rt;

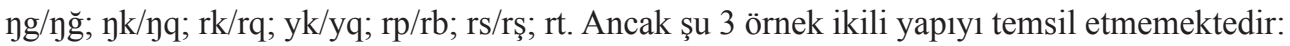
güyb, ğawq, ğıt. 


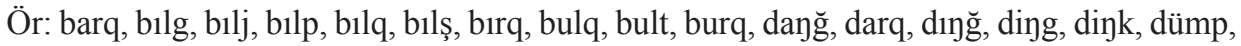
dürs, gilk, gilt, gümb/gümp, günk, gürp, güyb, ğanğ/qanğ, ğanq, ğarq, ğawq, ğırş, ğıyq, ğıyt, jalb, jalp, jalt, jarq, jelk, jelp, jılp, jılt, jımp, jırq, julq, kejk, larq, lars, mılj, mıığ, mınq, mırj, mırs, münk, payq, part, pırq, pırt, pısq, qalş, qalt, q11m, q1lq, q11t, q11ş, q1rt, q1yğ/q1yq, qorq, salp, samp, sayğ, sayq, sart, selk, selt, sılb, sılp, sılq, sılt, sınq, sı̄ğg, sırq, sırt, silk, solq, şalp, şamb, şarp, şart, şıld, şılq, şımb, şırp, şırt, şıyk, şing/şink, şorş, şurq, şüyk, talp, tạq, tarb, tars, tırp, tırs, tırt, tomp, tonq, wayq, warq, zınq, zirq, zırr, zijk, zonq.

2.1.4.4. ünlü-ünsüz-ünlü-ünsüz ile oluşanlar (VCVC): abır, adır, apı1, apır, äwil, ıbır, 1ך1l, 1ך1r, 1r11, 1s11, 1Z1门.

2.1.5. Beş Sesten Oluşanlar: Bu grupta yer alan örnekler kök birimlerin -1r, -1l ile uzatılması sonucu oluşmaktadır.

2.1.5.1. ünlü-ünsüz-ünsüz-ünlü-ünsüz (VCCVC): ejkil, ı๊q1l, ırsıll.

2.1.5.2. ünsüz-ünlü-ünsüz-ünlü-ünsüz ile oluşanlar (CVCVC): bajı1, baq1l, bezil, bıdır, bıjıl, darıl, dırıl, dızıl, digir, dikil, diril, dükil, düpir, düril, düsir, gibir, gübir, günir, güwil, jabır, jıbır, jığır, juğır, laqı1, lıq11, mayır, mırıl, möjir, parıl, patır, pırıl, pışır, pıtır, qaqı1, qırıl, qorıl, qurıl, saq11, saqır, satır, sıbır, sırıl, şaqır, şatır, şı1ıl, şıq11, şıtır, şuwı1, täkir, taq1l, taqır, tasır, tıpır, tıq11, toq11, tüpir, waj11, zaq11, zır1l, ziril, zuw1l.

2.1.6. Altı Sesten Oluşanlar: Bu grupta yer alan örnekler kök birimlerin -Ir, -Il, -Ay/-ıy ile uzatılması sonucu oluşmaktadır.

2.1.6.1. ünsüz-ünlü-ünsüz-ünsüz-ünlü-ünsüz ile oluşanlar (CVCCVC): barq1l, bılgaך,

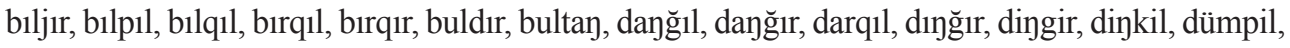
gilkil, gümbir, gümpil, günkil, gürsil, güybey, ğanğır/qanğır, ğanq1l, ğarq11, ğawq11, ğırş1l, ğıyq11, jalbır, jaltan, jaltıl, jaltır, jarqır, jelkil, jelpil, jılbır, j1ltıl, j1ltır, jımpıl, jırq1l, julq1l, keøkil, qaltıl,

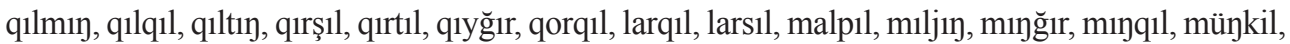

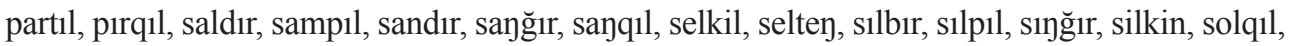

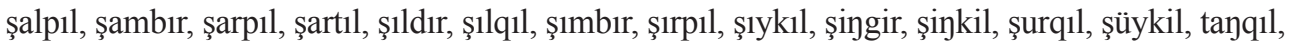
tarbay, tırp1l, tırs1l, tırtıy, tompay, tomp1l, tonq11, wayq11, warq11, zınq11, zırq11, zinkil.

\section{Yansımalarda Son Seste Bulunan Ses Düzeni}

\subsection{Birincil Biçimler}

\subsection{1. İki Sesten Oluşan Birincil Biçimler}

\begin{tabular}{|l|l|l|l|l|l|l|}
\hline $\mathbf{b} / \mathbf{p}$ & $\mathbf{l}$ & $\mathbf{y}$ & $\mathbf{r}$ & $\mathbf{s}$ & $\mathbf{w}$ & $\mathbf{z}$ \\
\hline ab & al & an & ir & is & äw & iz \\
ap & & in & & & uw & \\
ib & & & & & & \\
\hline
\end{tabular}




\subsection{2. Üç Sesten Oluşanlar Birincil Biçimler}

\subsubsection{Son seste tek ünsüz bulunanlar}

\begin{tabular}{|c|c|c|c|c|c|c|c|c|c|c|c|c|c|c|c|}
\hline \multicolumn{2}{|l|}{ b/p } & \multirow{2}{*}{$\frac{\mathbf{g} / \breve{\mathbf{g}}}{\operatorname{dig}}$} & \multirow{2}{*}{$\frac{\mathbf{j}}{\text { baj }}$} & \multicolumn{2}{|l|}{$\mathbf{k} / \mathbf{q}$} & 1 & & \multirow{2}{*}{$\frac{\eta}{\text { gün }}$} & \multicolumn{2}{|l|}{$\mathbf{r}$} & & & \multirow{2}{*}{$\frac{t}{b_{11}}$} & & \multirow{2}{*}{$\frac{\mathbf{z}}{\text { bez }}$} \\
\hline dab & lap & & & baq & $\mathrm{saq}$ & bil & güm & & bir & pir & düs & $\breve{g}_{1 S S}$ & & duw & \\
\hline düb & lıp & $\mathrm{j} 1 \breve{\mathrm{g}}$ & bij & dik & şaq & q1l & jim & qay & dar & qur & kis & kiş & pat & guw & $d_{1 z}$ \\
\hline düp & lüp & juğ & $\breve{g}_{1 j}$ & dük & ş1q & mil & $\operatorname{sim}$ & Z1y & dir & qor & pis & p1ş & pit & güw & \\
\hline gib & $\mathrm{sib}$ & & ğuj & ğaq & täk & ş1l & $\mathrm{z} 1 \mathrm{~m}$ & man & dir & qur & tas & & q1t & güw & \\
\hline güb & sip & & irj & laq & taq & & & & dür & sar & & & sat & şuw & \\
\hline $\mathrm{jab}$ & tıp & & $\mathrm{mij}$ & 11q & tıq & & & & ğur & sir & & & şat & zuw & \\
\hline $\mathrm{j} 1 \mathrm{~b}$ & & & şıj & qaq & toq & & & & mir & Z1r & & & şıt & & \\
\hline & & & waj & & $\mathrm{zaq}$ & & & & par & & & & & & \\
\hline
\end{tabular}

\subsubsection{Sonda iki ünsüz bulunanlar}

\begin{tabular}{|c|c|c|}
\hline Ip & $\eta g / n q / \eta k$ & rs \\
\hline elp & $\begin{array}{l}\text { ing } \\
\text { inq } \\
\text { enk }\end{array}$ & $\begin{array}{l}\text { ars } \\
\text { 1rs }\end{array}$ \\
\hline
\end{tabular}

\subsubsection{Dört Sesten Oluşan Birincil Biçimler}

\subsubsection{Sonda iki ünsüz bulunanlar}

\begin{tabular}{|c|c|c|c|c|c|c|c|c|c|c|c|}
\hline $\mathrm{lk} / \mathbf{l q}$ & It & $\mathrm{Ib} / \mathrm{lp}$ & Iș & $\mathrm{mp}$ & 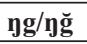 & 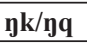 & rk/rq & yk/yq & $\mathbf{r p} / \mathbf{r b}$ & $\mathbf{r s} / \mathbf{r s ̧}$ & rt \\
\hline b1lg & bult & bilp & bilş & dümp & dayğ & $\operatorname{dink}$ & barq & ğıyq & gürp & ğırş & qurt \\
\hline bilq & gilt & jalb & qalş & gümp & ding & günk & burq & q1yq & şarp & qurş & part \\
\hline bulq & jalt & jalp & & jımp & dınğ & ğanq & birq & q1y & şırp & şorş & pirt \\
\hline gilk & j1lt & jelp & & samp & ğanğ & kenk & darq & şıłk & tarb & & tirt \\
\hline jelk & qalt & j1lp & & şamb & ming & minq & ğarq & şüyk & tırp & & sart \\
\hline julq & q1lt & malp & & şımb & qanğ & münk & jarq & & & & sirt \\
\hline q1lq & selt & salp & & tomp & sayğ & payq & jırq & & & & şart \\
\hline selk & silt & silb & & & $\operatorname{sing}$ & sayq & larq & & & & şırt \\
\hline silq & & silp & & & şing & sinq & qorq & & & & \\
\hline silk & & şalp & & & & şink & pirq & & & & \\
\hline solq & & talp & & & & $\operatorname{tanq}$ & sirq & & & & \\
\hline ş1lq & & & & & & tonq & şurq & & & & \\
\hline & & & & & & wayq & warq & & & & \\
\hline & & & & & & zinq & & & & & \\
\hline & & & & & & zink & & & & & \\
\hline & & & & & & zonq & & & & & \\
\hline
\end{tabular}




\section{2. İkincil Biçimler}

\begin{tabular}{|c|c|c|c|c|c|c|c|c|}
\hline \multicolumn{3}{|c|}{ 3.2.1. Beș Sesten Oluşanlar } & \multicolumn{6}{|c|}{ 3.2.2. Altı Sesten Oluşanlar } \\
\hline \multicolumn{2}{|l|}{-Ir } & \multirow{2}{*}{$\begin{array}{l}\text {-Il } \\
\text { bezil }\end{array}$} & \multicolumn{2}{|c|}{-II } & \multicolumn{2}{|l|}{$-\mathbf{I r}$} & \multirow{2}{*}{-Ay } & \multirow{2}{*}{$\frac{-\mathbf{I y}}{\text { miljin }}$} \\
\hline bidır & jiğır & & gilkil & silp1l & biljır & qanğır & & \\
\hline dabir & mayır & dizıl & güykil & solq1l & buldır & q1yğır & güyben & q1lmin \\
\hline digir & mönir & güwil & ğanq1l & ş1lq11 & dayğır & saldır & jaltan & qultın \\
\hline gibir & saqur & saq1l & ğawq11 & şırp1l & dınğır & sandir & selten & tirtin \\
\hline günir & sibir & ş1q1l & malp1l & Ş1yk1l & dingir & sayğır & tarbay & \\
\hline jabir jıbır & tüpir & şuwıl & pirq1l & tayq1l & ğanğır & silbir & & \\
\hline & & taq1l & samp1l & wayq1l & jalbır & sinğır & & \\
\hline & & waj1l & selkil & warq1l & j1lbir & şambır & & \\
\hline & & zaq1l & & & minğır & şıldır & & \\
\hline & & ziril & & & & şımbır & & \\
\hline & & zuw1l & & & & & & \\
\hline
\end{tabular}

\section{Yansımalarda Ön Seste Bulunan Ses Düzeni}

\section{1. Ön Seste Kullanılan Ünlüler:}

\begin{tabular}{|c|c|c|c|c|c|c|c|}
\hline \multicolumn{2}{|l|}{$\mathbf{a}$} & \multirow{4}{*}{$\begin{array}{l}\text { ä } \\
\text { äwil } \\
\text { äwkiy } \\
\text { äwpil }\end{array}$} & \multirow{3}{*}{$\begin{array}{l}\text { e } \\
\text { elp } \\
\text { eykil }\end{array}$} & \multicolumn{2}{|l|}{1} & \multirow{3}{*}{$\begin{array}{l}\text { ö } \\
\text { ökir- } \\
\text { ökiren }\end{array}$} & \multirow{2}{*}{$\frac{\mathbf{u}}{\mathrm{uu}}$} \\
\hline abir & ay & & & 1bır & ir1l & & \\
\hline adır & ap1l & & & 11 & 1rjiy & & uw \\
\hline alaq & apır & & & ingä ıłı1 & irsil & & uw1l \\
\hline alba & aq1r- & & & ıjır & 1s1l & & uура-juypa \\
\hline an-tan & ars & & & inq1l & 1zıl & & \\
\hline & & & & & $1 \mathrm{Z} 1 \mathrm{n}$ & & \\
\hline
\end{tabular}

\section{2. Ön Seste Kullanılan Ünsüzler}

\begin{tabular}{|c|c|c|c|c|c|c|c|c|c|c|c|}
\hline \multicolumn{2}{|l|}{ b } & \multicolumn{2}{|l|}{ d } & \multicolumn{2}{|l|}{$\mathbf{g} / \breve{\mathbf{g}}$} & \multicolumn{2}{|l|}{$\mathbf{j}$} & \multicolumn{2}{|l|}{$\mathbf{k} / \mathbf{q}$} & \multirow{2}{*}{\begin{tabular}{|l|}
1 \\
lap
\end{tabular}} & \multirow{2}{*}{$\begin{array}{l}\mathbf{m} \\
\text { malp1l }\end{array}$} \\
\hline bajalaq & biljır & dayğ 11 & dirıl & ğanğır & ğıyq1l & jabır & jibir & kekir- & q1lq1l & & \\
\hline baj1l & bilp1l & dayğır & dizıl & ğanq1l & gübir & jalbir & jiğır & keykil & qultin & laq1l & mayır \\
\hline baq1l & bilq1l & dar1l & dükil & ğaqaq & gümbir & jalp & j1lt & kis & qirıl & larq11 & $\mathrm{mij}$ \\
\hline baqır & bilş & darq1l & dümpil & ğarq11 & gümpil & jalt & j1ltıl & kiş & q1rş11 & lars & miljın \\
\hline barq11 & birq1l & digir & düpir & ğawq1l & günir & jaltan & j1ltır & qalt1l & qurtıl & lars1l & minğır \\
\hline barqur & birqur & dikil & düril & gibir & günkil & jalt1l & jımp1l & qanğır & q1yğır & lip & minq1l \\
\hline bezil & & dingir & dürsil & $\breve{g} 1 j$ & gürp & jaltır & jırq1l & qay & qoril & liq1l & mirıl \\
\hline bidir & buldır & dı̄ğır & düsir & gilkil & gürsil & jarqur & juğır & qaq11 & qorq1l & lüp & mirj \\
\hline bij & bulq & dinkil & duw & gilt & guw & jelkil & julq11 & qaqur & qur1l & & mirs \\
\hline bij1l & bultan & diril & & ğ1rşı1 & güwil & jelpil & juwdır & q1lmin & & & mönir \\
\hline bilgay & & & & ğışır & güyben & & & & & & müykil \\
\hline & & & & & & & & & & & \\
\hline
\end{tabular}




\begin{tabular}{|c|c|c|c|c|c|c|c|c|c|c|c|}
\hline p & & $\mathbf{S}$ & & ș & & & $\mathbf{t}$ & & $\mathbf{w}$ & $\mathbf{z}$ & \\
\hline panq & pirq1l & saldır & saqır & şak & ş1j1l & şıtır & täkir & tarbay & waj & zaq1l & ziril \\
\hline par1l & pirr & samp1l & sar & Şalpıl & şıldır & Şıykıl & talp & tars & waj1l & $\mathrm{zlm}$ & zırıl \\
\hline partıl & pirt & sandır & sart & şambır & ş1lq11 & şurq1l & tanq1l & tasır & wayq1l & zinq & zırq11 \\
\hline pat & pis & sayğır & satır & şaq1l & Şımbır & şuw & taq & tıpır & warq1l & Zınq11 & zırrık \\
\hline patır & pışır & sayq1l & selkil & şarpıl & şingir & şuw1l & taq1l & tıq1l & & Z1n & zonq \\
\hline pir & pisqir & saq1l & selten & şartıl & şinkil & şüykil & taqır & & & zinkil & zuw \\
\hline pir1l & pitır & & $\operatorname{sim}$ & şatır & Şırp1l & & & & & Z1r & zuw1l \\
\hline & & & Sir & & & & & & & & \\
\hline
\end{tabular}

\section{Ses Bilgisi Tespit ve Değerlendirmeler}

Bu bölümde yansıma kelimelerde ses ve anlam ilişkisi kurulmaya çalışılmakta ve yansıma kelimeler üzerine dikkat çeken bazı hususlar değerlendirilmektedir. Bu bölüm hazırlanırken Günay Karaağaç'ın “Türkçenin Dil Bilgisi” ve Ceyhun Vedat Uyğur’un “Karakalpak Türkçesi Grameri” adlı çalışmalarında geçen ses özelliklerinden faydalanılmıştır.

\section{1. Ünlü seslerle ilgili}

Karakalpak Türkçesinde yansıma kelimeleri incelediğimizde, ünlü seslerin değişkenlik gösterdiğini ve sabit olmadığını görmekteyiz. Ünlüler değiştiğinde anlam farklılığı ortaya çıkmaktadır. Örneğin, bajılda-: öfkeyle bağırmak, kötü sözler söylemek (KTS 55); bijılda-: çok konuşmak, söylenmek (KTS 83). Birinci örnek kalın, kaba, yüksek bir sesi ifade ederken ikinci örnek yüksek bir sesi temsil etmemektedir. Bir başka örneğe baktığımızda ise ağır makinelerin çıkardığı yüksek ve sert bir sesin /a/ ile oluşan örnekte yer aldığını; aletlerden doğal olarak çıkan rutin sesin ise /1/ sesi ile oluşan örnekte geçtiğini görmekteyiz. Yani /a/ sesi daha kalın ve güçlü bir sesi temsil ederken /1/ sesi daha hafif, ince bir sesi temsil etmektedir. darllda-: genellikle ağır makine ve motorların ses çıkarması, harıldamak (KTS 114); dırılda-: çalışan alet, motor vb. ses çıkarmak (KTS 122). Bunun gibi örneklerin sayısını arttırmak mümkündür. Örneğin: manqıldaq: geveze, ileri geri konuşan, patavatsız (KTS 380); mıłqılda: burnundan konuşmak, anlamsız konuşmak (KTS 394). Görülmektedir ki yansımalarda ünlü seslerin değişkenlik göstermesi anlama güçlü-güçsüz, şiddetli-şiddetsiz, sürekli-süreksiz, yoğun-hafif gibi anlamlar katmaktadır. Yansıttıkları sesler bakımından; geniş ünlüler, dar ünlülere göre daha güçlü sesleri ifade eder. Dar ünlüler ise geniş ünlülere göre daha zayıf ve belirsiz sesleri ifade ederler: qorqılda- sıv1 nesneyi höpürdeterek içmek" anlamında ve çıkan sesin kaba ve yoğun olduğunu ifade eder. qılqılda- "bir sıvıyı ses çıkararak içmek" ise "lık lık" içmek anlamında kullanılmakta, kabalıktan ve sesin çok çıkmasından ziyade sıvı tüketilirken çıkan olağan bir sesi temsil eder. Başka bir örnek olarak çatırda- ve çıtırda- anlamındaki fiillerde aynı durumu görmekteyiz. şartılda-: bir şeyin 'şart (çat).' diye ses çıkarması, çatırdamak, şırt et-: çıt diye kırılmak. Birinci kullanımda daha sert bir ses ifade edilirken ikinci örnekte daha ince bir ses ifade edilir.

Tespit edilen örneklerde görülmektedir ki taklit ya da tasvir edilen sesin nitelikleri farklı özelliklerdeki ünlülerin kullanılmasıyla ifade edilmektedir. Dar ve geniş ünlülerin ayrımı ile 
ses ve sözcük arasında bir bağ kurulmakta ve yüksek-az, güçlü-güçsüz, uzun-kısa gibi anlamsal farklılıklar geniş ve dar ünlülerin kullanılmasıyla belirlenmektedir. Karakalpak Türkçesinde kök yansımalarda kalın ünlüler, ince ünlülere göre daha çok kullanılmaktadır. Ayrıca /o/ ve /ö/ sesinin genel olarak yaygın olmadığına, bir iki örnekte yer aldığına ve en çok /a/ ve /1/ sesinin kullanıldığına rastlanmaktadır. /e/ ve /i/ sesinin kullanımı ise yoğun değildir.

\section{2. Ünsüz Seslerle İlgili}

\section{$/ \mathbf{b}-\mathbf{p} /$}

Sonda bulunan çift ünsüzlerden bazılarının son sesi /p/ ile bitmektedir: lb/lp, rp/rb. Sondaki /p/ sesi yumuşayarak/b/ sesine dönüşebilmektedir: sılb, sılp, jalb, jalp, tırp, şarp. Yansımaların ön sesinde yaygın olarak /b/ ve /p/ seslerini görmekteyiz. /p/ ile biten örneklerde sesin ya da hareketin keskin ya da kısa olduğu, aniden olup bittiği görülür. Bu durum son seste /p/ sesinin bulunmasıyla ilgilidir: şalp et-: suyun "şalp" diye ses çıkarması (KTS 528). elp et-: birden görünme, aniden görünüp yok olma (KTS 134). jelpilde-: bir inip bir çıkmak (KTS 238); şırpılda-: 1. hızlanmak, çabuk çabuk hareket etmek 2. ses çıkarmak, vurmak çalmak (KTS 544).

\section{/d-t/}

Yansıma köklerin ön sesinde patlayıcı /d/ sesi görülürken son seste ve çift ünsüzlerde bu ses görülmemektedir: dạğır, darıl, dikil, dingir vb.

Patlayıcı, tonsuz /t/ sesi ise yansıma köklerin başında, sonunda ve çift ünsüzlerde sık görülen bir sestir: pat, pıt, q1t, selt, sılt, jalt, jılt, tırt, sart, şart, sırt, tạqıl, taq1l vb. Çift ünsüzlerde /r/ ile /1/ sesinin ardından kullanılır ve sesin ya da hareketin aniden olduğunu, birdenbire olup bittiğini anlatır: jaltılda-: parlamak, bir görünüp bir kaybolacak şekilde 1şık saçmak (KTS 224); partılda-: sesin patırdayarak gümbürdeyerek çıkması (KTS 455); pırt et-: sıvının/ suyun birdenbire sıçraması, fışkırması (KTS 464). /d/ ve /t/ sesi patlayıcı olma özelliğinden dolayı şiddetli ve sert sesleri anlatırken kullanılmakta ve bazen sert olan /t/ sesi yerini /d/ sesine bırakır: tayqılda-: bağırarak ve sert konuşmak (KTS 564); darqılda-: çok konuşmak, gevezelik etmek (KTS 114). digirle-: bir şeyin düz olmayan bir yerde tıkırdaması, ses çıkarması (KTS 122); taqılda-: "tak tak" ses çıkarmak (KTS 559).

Yansımaların son sesi /t/, /p/ sesleri ile bitiyorsa hareketin ya da sesin hızlı ve aniden gerçekleştiğini ya da sert ve keskin bir şekilde meydana geldiğini ifade eder: jllp-jılp et-: hızlı ve çevik hareket etmek (KTS 242); jlltılda-: bir sönüp bir yanmak, yanıp sönmek (KTS 243); şırt et-: çıt diye kırılmak (KTS 544); pıt-şıt bol-: parçalanmak (KTS 465) vb.

\section{$/ \mathbf{f} /, / \mathbf{h} /$}

Bu sesler daha çok yabancı kelimelerde kullanıldığı için yansımalarda onların örneklerine rastlanmamaktadır. Karakalpak Türkçesi yansımalarda rastlanmayan bir diğer ses /ç/'dir. 
Türkçedeki /ç/ sesi Kapakalpak Türkçesinde yerini /ş/ sesine bıraktığından dolayı örneklerde tanıklanmamaktadır.

\section{$/ \mathbf{j} /$}

Türkçe kelimelerde bulunmayan /j/ sesinin kullanımına Karakalpak Türkçesi yansıma köklerde rastlanmaktadır. /j/ sesi Karakalpak Türkçesinde aslında /y/ sesinin bazen de /c/ sesinin yerine kullanılmaktadır. /j/ sesi daha çok yansımalar ile yabancı dilden giren kelimelerde görülür: Ör: baj, bıj, ğıj, ğuj, mıj, şıj, waj, jabır, jıbır, jı̆̆ır, jım, juğır vb.

\section{$/ \mathbf{g} /, / \breve{g} /, / \mathbf{k} /$ ve $/ \mathbf{q} /$}

Karakalpak Türkçesinde / $\breve{g} /$ sesi /g/ sesinin, /q/ sesi de /k/ sesinin daha sert ve güçlü şeklidir. Ön seste, son seste ve çift ünsüzlerin sonunda bu dört sesin sık kullanımına rastlanmaktadır: ğanğır, ğanq11, gübir, günkil, kekir-, kejkil, kiş, qanğır, dig, jığ, juğ, baq, dik, ke- vb. Yansımalarda önde ve sonda /g/ ve /k/ sesinin örnekleri sert şekillerine göre daha azdır. Çift ünsüzlerde 1, y, r,

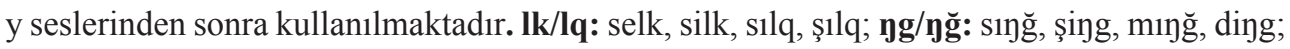

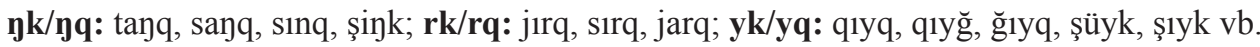

/ $/ \mathrm{g} /$ ve /q/ sesleri daha sert, güçlü ve yoğun seslerde kullanılırken /g/ ve /k/ bu seslerin daha hafif ve yumuşak şekillerini temsil etmektedir. ğarqılda-: yüksek sesle, kahkahayla gülmek (KTS 180), keøkilde-: ağlarken veya gülerken kesik kesik ses çıkarmak, kıkırdamak (KTS 266); ğawqulda-: yerli yersiz yüksek sesle konuşmak (KTS 181); gübir-gübir: 1. ancak işitilecek kadar insanların konuşması, fısır fisır 2. kendi kendine konuşma, fısıldama, fisıltı (KTS 173).

\section{$/ \mathbf{l} /$}

Türkçede ve Karakalpak Türkçesinde yabancı kelimeler dışında ön seste bulunmayan /1/ sesinin yansımalarda kullanıldığını görmekteyiz: lap, laqı1, larqıl, larsıl, lıp, lıq, lıq11, lüp. /1/ sesi başta kullanılabildiği gibi hem kelime sonunda hem de çift ünsüzlerin ilk sesinde yaygın olarak kullanılmaktadır: l: bıl, qı1, mıl, şı1. lk/lq: selk, silk, sılq, şılq, solq, jelk, julq, qılq, bılq, bulq, bilg, gilk. It: selt, sılt, jalt, j1lt, qalt, q1lt, bult, gilt. lb/lp: talp, silb, sılp, jalb, jalp, jelp, j1lp, malp, salp, şalp, bılp. Iş: qalş, bılş.

\section{$/ \mathbf{m} /, / \mathbf{n} /, / \mathbf{y} /$}

$/ \mathrm{m} /, / \mathrm{n} /, / \mathrm{y} /$ seslerinin yumuşak ve sert çiftleri yoktur. Kelime başında $/ \mathrm{m} /$ sesi kullanılırken /n/ ve /n/ sesleri bulunmaz: mayır, mij, mıljı̀, mınğır, mııqıl. Yansıma köklerin sonunda ise

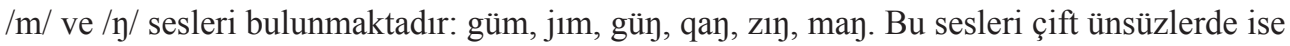

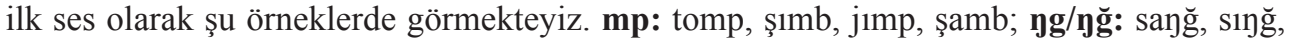

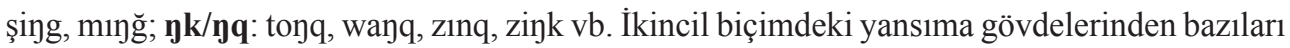

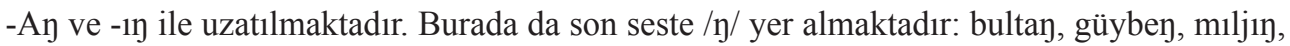
qılmın vb. Daha çok son seste ve çift ünsüzlerin ilk sesinde rastlanan / $\mathrm{y} /$ sesi ise sesin yankılı çıktığını göstermektedir. 
$/ \mathbf{r} /$

Yansıma kelimelerde ön seste $/ \mathrm{r}$ / sesinin kullanımına rastlanmazken son ses olduğu durumlarda /r/nin “pırr, zırr” örneklerindeki gibi uzayarak tekrar ettiği görülmektedir. İkincil biçimdeki yansımaların sonunda titrek, akıcı ünsüz olan /r/ sesinin sık kullanıldığına rastlanmaktadır. Ör: bıdır, digir, gibir, jabır, mayır, bıljır, buldır, dı̄ğır, dịgir, mıฏğır vb. Birincil biçim (CVC) yapısının son sesinde /r/ sesinin yine yaygın olarak kullanıldığı görülür. Ör: dar, dır, dir, dür, ğur, mır, par, pır, qır, qor, qur vb. Ayrıca birincil biçim (CVCC) yapısında çift ünsüzlerin ilk sesi olarak görülmektedir. rk/rq: zırq, warq, şurq, sırq; rs/rş: şorş, qırş, ğırş; rt: sart, şart, sırt, şırt, part.

\section{/s/ ve /ş/}

/s/ ve /ş/ sesi yansıma köklerde önde, sonda ve çift ünsüzlerde kullanılmaktadır: düs, kis, pıs, tas, saqır, sar, sart, ğış, kiş, pış, şıldır, şılq11. Iş: qalş, bılş; rs/rş: q1rş, ğırş vb. Çift ünsüzlerde /1/ ve /r/ sesinden sonra getirilmektedir. Özellikle (CVC) kalıbındaki birincil biçimler genellikle hızlı ve çabuk olma, birden olma, devam etme anlamlarını taşımakta ve sesin kısa sürdüğünü ifade etmektedir: sart et-: iki şeyin birbirine dokunması sonucu "sart" diye ses çıkarmak (KTS 492); sılq et-: birden düşmek, boşalıp düşmek (KTS 503); sılt et-: kımıldamak, hareket etmek (KTS 503); sırqıra-: suyun ses çıkararak akması, şırıldamak (KTS 505); şalp et-: suyun "şalp" diye ses çıkarması (KTS 528); şıjılda-: kaynayarak ses çıkarmak, fokurdamak, cızırdamak (KTS 541); şırt et-: çıt diye kırılmak (KTS 544).

\section{/w/}

Çift dudak ünsüzü olan /w/ sesi, ön seste ve yansıma köklerin son sesinde bulunmaktadır: äw, guw, güw, şuw, waj, wajıl, wayq1l vb.

\section{$/ \mathbf{y} /$}

Ön seste ve kök yansımaların son sesinde görülmeyen /y/ sesi yk/yq kalıbındaki çift ünsüzün ilk sesini oluşturmaktadır: şüyk, şıyk, q1yq, q1yğ, ğıyq.

\section{$|\mathbf{z}|$}

/z/ sesi yansımaların ön sesinde bulunmaktadır: zırıl, zırqı1, zırrık, zonq, zuw, zuwıl. Yansıma köklerin son sesinde nadiren rastlanan /z/ sesi çift ünsüzlerde yer almamaktadır: bez, dız.

\subsection{Uzatılmış Yansımalarla İlgili}

\section{-Ir ve-Il}

İkincil biçimde oluşan yansımalar -Ir, -Il, -Ay, -1n ile uzatılan örneklerdir. Bazı örneklerde hem kök hem de uzatılmış şekildeki sözcüklerin bulunduğuna rastlanmaktadır. Bu durum sözcügün uzatılmasını gerektiren bir nedene ihtiyaç duyulduğunu göstermektedir. Kök hâlin 
kullanımı, anlamı karşılamadığı için yeni bir yapıya ihtiyaç duyulmuş olmalıdır. Hareketin hızını, şiddetini vb. özelliklerini belirtmek amacıyla iki farklı uzatma şekli tercih edilmiş olmalıdır. Aynı kök hem -Ir hem de -Il ile uzatılabilmektedir. Bu durumda da aynı işlevdeki iki farklı yapının kullanılıyor olması bir anlam farklılığı yaratmalı, -Ir ile -Il'ın kattığı farklı anlamlar ya da ayrımlar olmalıdır. Bu kapsamda şu örnekleri ele alalım. diggirle-: sık sık veya tekrar tekrar gelmek (KTS 123), dịkilde-: bir şeyin peşinden dingil dingil gelmek (KTS 123). Dingirle- ve dịkilde- sözcükleri yakın anlamdadır ancak farklılık taşıdığı açıkça görülmektedir. Birinci örnek "dingirle-“" aralıklı yapılan, kesik kesik yapılan bir eylemi anlatmak için kullanılırken ikinci örnek "dijkilde-“ ise aralıksız ve kesintisiz yapılan bir eylemi ifade etmektedir. Bir başka örnek ise; digirle-: bir şeyin düz olmayan bir yerde tıkırdaması, ses çıkarması (KTS 122), dikilde-: yüreğin sık sık ve güçlü atması, yüreği güp güp atmak (KTS 122). Birinci örnek düz olmayan bir yere temas ettiği için kesik kesik, aralıklı çıkan bir sesi ifade etmekteyken ikinci örnek aralıksız devam eden bir sesi anlatmaktadır. şingirle-: sözü tekrar tekrar söylemek (KTS 546), şigkilde-: ince sesle konuşmak (KTS 546). Bu iki örnekte de aynı durumu görmekteyiz. -Ir ile uzatılan örnek eylemin aralıklarla yapıldığını gösterirken -Il ile uzatılan örnek daha yumuşak bir sesi ve devamlılığı anlatmaktadır. Buradaki örneklerde yansıma kökler uzatılırken -Il ve -Ir rastgele getirilmemektedir. Her iki yapının da kattığı devamlılık-devamsızlık, sürekliliksüreksizlik anlamları bulunmaktadır. Uzatılan örneklere baktığımızda -Ir öncesinde b, d, g, $\breve{g}$, j, k, y, p, q seslerini, -Il ise j, k, p, q, r, w, z seslerini almaktadır.

\section{SONUÇ}

Yansımalardaki ses özelliklerini genel hatlarıyla ortaya koymayı amaçladığımız bu çalışmayla Türk dilinin her kolunda olduğu gibi Karakalpak Türkçesinde de yansıma sözlerin geniş ve özel bir yer tuttuğunu görmekteyiz. Yansıma köklerin yani birincil biçimlerin tek başına kullanımına sık rastlanmamakta ancak yansıma kökten türetilen uzatılmış biçimler yani ikincil biçimlerin kullanımı ise daha fazladır.

Karakalpak Türkçesinde yansımalar taklit ve tasvir yansıma kelimeler olmak üzere ikiye ayrılmaktadır. Karakalpak Türkçesi, yansıma kelimelerde hece başı, ortası ve sonunda bulunan bazı seslerin nitelikleri anlam ayırt edici özelliğe sahiptir. Yansımalar, ünsüz seslerin kelime başında ya da sonunda gelişi yönünden Türkçenin ve Karakalpak Türkçesinin genel fonetik kurallarına uymaktadır.

Karakalpak Türkçesi kök birimlerde ünlü seslerin değişkenlik göstermesi, anlama güçlü-güçsüz, şiddetli-şiddetsiz, sürekli-süreksiz, yoğun-hafif, yüksek-az gibi anlamlar katmaktadır. Yansıttıkları sesler bakımından geniş ünlüler, dar ünlülere göre daha güçlü sesleri ifade eder. Dar ünlüler ise geniş ünlülere göre daha zayıf ve belirsiz sesleri ifade ederler. Örneğin, qorqılda- "sıv1 nesneyi höpürdeterek içmek" anlamında ve çıkan sesin kaba ve yoğun olduğunu ifade eder. qulqılda- "bir sıvıyı ses çıkararak içmek" ise "lık lık" içmek anlamında kullanılmakta kabalıktan ve sesin çok çıkmasından ziyade sıvı tüketilirken çıkan olağan bir sesi temsil eder. 
Görülmektedir ki yansıma kelimelerde ses-anlam ilişkisi bulunmakta ve yansımaların, kendine özgü ses ve hece sistemiyle söz varlığı oluşmaktadır. Yansıma kelimeler ses sayıları açısından ele alındığında bir, iki, üç, dört, beş ve altı sesten oluştuğu görülmektedir. Ünlü ve ünsüz dizilişi bakımından ise birincil biçimler şu şekillerde oluşmaktadır: $\mathrm{V}, \mathrm{CV}, \mathrm{VC}, \mathrm{CVC}$; VCC; CVCC. İkincil biçimler ise VCVC; VCCV; VCCVC; CVCVC; CVCCVC şeklinde oluşmaktadır. Bu yapılardan en çok CVC ve CVCC yapısının kullanıldığı görülmektedir.

Fonetik açıdan bakıldığında yansıma kelimelerin son sesinde belirli yapıların ve seslerin kullanımına rastlanmaktadır. Karakalpak Türkçesi yansıma kelimelerin ön sesinde b, d, g/ğg, j, k/q, l, m, p, s, ş, t, w, z ünsüzlerinin kullanımını görmekteyiz. Son seste kullanılan ünsüzlere baktığımızda ise tek sesten oluşan birincil biçimlerde (V): a, ö, u; iki sesten oluşan birincil biçimlerde (CV): b/p, k/q, l, y, r, s,w, z; üç sesten oluşan birincil biçimlerde (CVC): b/p, g/ ̆g , $\mathrm{j}, \mathrm{k} / \mathrm{q}, \mathrm{l}, \mathrm{m}, \mathrm{y}, \mathrm{r}, \mathrm{s}, \mathrm{s}, \mathrm{t}, \mathrm{w}, \mathrm{z}$ seslerini tespit etmekteyiz. Birincil biçim (CVCC) yapısındaki yansıma kelimelerin son seslerinde ise 12 tane ikili ünsüz kullanıldığı görülmektedir. Bunlar şu ikili yapılardır: lk/lq; lt; lb/lp; lş; mp; rt; ıg/ığ; ık/ıq; rk/rq; yk/yq; rp/rb; rs/rş; rt.

Birincil biçimler çoğunlukla -Ir; -Il ile uzatılarak ikincil birimler oluşmakta, daha az örnekte ise -Ay; -1y; kullanımı ile birincil biçimlerin uzatıldı̆̆ 1 görülmektedir. Ör: bultạ, dızıl, güwil, jıbır, jığır, mıljı̣, sılpıl, zırqıl vb. Yansıma kökler uzatılırken -Ir ve-Il belirli anlamları katmaktadır. Her iki yapının da kattığı devamlılık-devamsızlık, süreklilik-süreksizlik anlamları bulunmaktadir.

Yansımalarda birincil ve ikincil biçimler yanına yardımcı fiil alarak yapım ekleriyle genişletilerek ya da ikileme oluşturarak cümlede kullanılmaktadır. Ör: bıq-jıq, bırq-bırq et-, birqilda- vb.

Yapı olarak yansımaların kullanımlarına baktığımızda ise şunları söyleyebiliriz. Birincil ve ikincil biçimler, fonetik değişikliğe uğramadan tek başına isim ya da fiil olarak kullanılabilir: burq, bık- vb. Yansımalar yardımcı fiillerle ya da farklı fiillerle beraber kullanılabilir: baj et-, dür dür et-, jaltạ bol-, jım bol-, jınq etpe-, mırs mırs etip kül- vb. Yansımalar ikileme şeklinde anlamı pekiştirmek amacıyla kullanılabilir ve ikilemelerdeki ünlü sesler değişime uğrayabilir ya da ikinci kelime, birinci kelimenin önüne ünsüz ses getirilmesi yoluyla yani ünsüz türemesi vasıtasıyla oluşabilir. baj-baj, bıj-bıj, bırq-bırq, alba-dalba, apır-tapır vb.

Sonuç olarak eski ve yeni yazılı eserlerimiz, lehçelerimiz, konuşma dilimiz, ağız söz varlığımız incelenerek yansıma kelimeler tespit edilmeli; ses, şekil ve anlam açısından incelenen yansımaların sözlüğü hazırlanmalıdır. Bu çalışma Karakalpak Türkçesi ile sınırlandırılmıştır ancak Türkiye Türkçesi ve diğer lehçelerdeki yansıma kelimelerde de ses ve sözcük arasında ilişki kurmak mümkündür. Türkçenin yapısını ve oluşumunu anlayabilmek adına yansıma kelimeler üzerine farklı açılardan bakılmalı ve daha çok çalışma yapılmalıdır. Yansımaların tespitiyle birlikte seslerin kattığı anlamlara dikkat edilmeli ve sözlüklerdeki yansıma kelimelerin anlamları daha net ve anlaşılır biçimde geliştirilmelidir. 


\section{KISALTMA}

KTS: Karakalpak Türkçesi Sözlüğü

Hakem Değerlendirmesi: Dış bağımsız.

Çıkar Çatışması: Yazar çıkar çatışması bildirmemiştir.

Finansal Destek: Yazar bu çalışma için finansal destek almadığını beyan etmiştir.

Peer-review: Externally peer-reviewed.

Conflict of Interest: The author has no conflict of interest to declare.

Grant Support: The author declared that this study has received no financial support.

\section{KAYNAKÇA/REFERENCES}

Aksan, D. (2009). Her Yönüyle Dil Ana Çizgileriyle Dilbilim. 1.2.3. Ciltler. Ankara: TDK.

Atabay, Neşe,; Kutluk, İ. ve Özel, S. (1983). Sözcük Türleri. Ankara: TDK.

Ay, Akyıldız, D. (2020, Ekim). Türkçede Sözlükbirim Olarak Yansıma Sözcükler ve Sözlükselleşme

Dereceleri. XII. Uluslararası Dünya Dili Türkçe Sempozyumu. Ankara.

Banguoğlu, T. (1941). Dil Bahisleri 1. İstanbul: Vakıt matbaası.

Banguoğlu, T. (2007). Türkçenin Grameri. (8.Basım). Ankara: TDK.

Baytok, A. (2014). Kırgız Türkçesinde Yansımalı Sözcükler. Modern Türklük Araştırmaları Dergisi. 11(3).106-145.

Biray, N. (2014). Kazak Türkçesinde Yansımalı İkilemeler - Ses Özellikleri Bakımından. VI. Dünya Dili Türkçe Sempozyumu, 2., 1091-1105.

Çağatay, S. (1978). Türk Lehçeleri Üzerine Denemeler. Ankara Üniversitesi: DTCF Yayınları.

Deny, J. (1995). Türk Dili Gramerinin Temel Kuralları (Türkiye Türkçesi). Ankara: TDK.

Ergin, M. (2019). Türk Dil Bilgisi. İstanbul: Boğaziçi yayınları.

Gencan, T, N. (2001). Dilbilgisi. Ankara: Ayraç Yay.

Gültek, V. (2012). Rusça Türkçe Sözlük. İstanbul: Multılıngual.

İskakov, A. (1991). Kazirgi Kazak Tili. Almatı: Ana Tili.

Janjua, D.K. (2000). Japoncada Yansımalı Sözcükler. (Yüksek Lisans tezi) Ankara Üniversitesi. Sosyal Bilimler Enstitüsü, Ankara.

Karaağaç, G. (2019). Türkçenin Dil Bilgisi. Ankara: Akçağ.

Karakaş, D. (2003). Kazak Türkçesinde Yansıma Yoluyla Ortaya Çıkan Söz Varlı̆̆ı. Erciyes Üniversitesi, Sosyal Bilimler Enstitüsü, Kayseri.

Korkmaz, Z. (2009). Türkiye Türkçesi Grameri, Şekil Bilgisi. (3. Bask1). Ankara: TDK

Naskali, E.G. (2007). “Türk Dünyası Gramer Terimleri Kılavuzu” Ankara: TDK.

Omuralieva, A. (2019). Yansımalı Kelimeler Üzerine Bir Bibliyografya Denemesi. Uluslararası Türk Lehçe Araştırmaları Dergisi (TÜRKLAD). 3(2). 257-267.

Özbek, E. E. (2019). Tuva Türkçesinde Yansıma Sözler. Türkbilig Dergisi, (38). 11-30. 
Serebrennikov, B.A.ve Gadjieva, N.Z. (2018). Türk Yazı Dillerinin Karşılaştırmalı Tarihî Grameri. Ankara: TDK.

Seytnazarova, İ. (2006). Hazirgi Karakalpak Tili Morfologiya. Nökis: Berdak Atındağı Karakalpak Memlekettik Üniversiteti.

Şınnazarova, C.J. ve Aljanova, G.E. (2019). Yeliktewiş Sözlerdi Okıtıw Usılları. Bastawış “Telimdi Modelnizatsiyalaw Protsessleri: Maşkalalar hem Şeşimler” atamasındagı respublikalık ilimiy-teoriyalık konferantsiya materialları. Nökis: NMPİ baspası.

Tazhieva, A. (2020). Kırgız Türkçesinde Yansıma Kelimeler. (Yüksek Lisans Tezi) Pamukkale Üniversitesi, Sosyal Bilimler Enstitüsü, Denizli.

Uyğur, C, V. (2018). Karakalpak Türkçesi Grameri. Ankara: TDK.

Uyğur, C, V. 2019. Karakalpak Türkçesi Sözlüğ̈̈. Ankara: TDK.

Vardar, B. (1988). Açıklamalı Dilbilim Terimleri Sözlüğü. İstanbul: ABC Kitabevi.

Zülfikar, H. (1995). Türkçede Ses Yansımalı Kelimeler. Ankara: TDK. 


\section{EK 1}

\section{Yansıma Yoluyla Oluşan Söz Varlığı}

abır-sabır: apar topar, alelacele (KTS 14).

adır-budır: yönlü yönsüz, langır lungur, olur olmaz (KTS 14).

al: acıyı, derdi bildiren ünlem (KTS 20).

alaqla-: şaşırmak, hayrete düşürmek, ne yapacağını bilmemek (KTS 21).

alba-dalba: yırtık, pejmürde, perişan (KTS 21).

alba-dulba: yırtık, pejmürde, perişan (KTS 21).

alba-julba: yırtık (KTS 21).

ałqılda-: içinde ne varsa söylemek, açılmak (KTS 26). ałqır-: haykırmak, bütün gücüyle bağırmak (KTS 26). apıl-tapıl: zorla yürüme, düşe kalka yürüme (çocuk için) (KTS 27).

apır-tapır: apar topar, çabuk çabuk (KTS 22). aqır-: yüksek sesle bağırmak, haykırmak (KTS 18).

arsılda-: öfkeyle bağırmak, ağız dalaşı etmek; havlamak, ulumak (KTS 29).

äwilde-: bebeklerin insanlara bakarak ilk konuşması, ilk cevap verişleri (KTS 51).

äwip: içten içe nefes alma, nefes sesi, boğazdan ses çıkarma (KTS 51).

äwkiy-: yersiz ses çıkarmak, kaba ses çıkarmak (KTS 51).

äwpilde-: 1. edepsizce bağırmak, haykırmak 2. köpeğin havlaması (KTS 51).

äwpildek: gürültücü yaygaracı (KTS 51).

baj et-: birden söylemek, kötü söz ile sövmek, edepsizlik etmek (KTS 55).

baj-baj et-: bağırıp çağırmak, öfkelenmek (KTS 55).

bajılda-: öfkeyle bağırmak, kötü sözler söylemek (KTS 55).

bajıldaq: kötü söz söyleyen (KTS 55).

bajıldas-: 1. tarafların, aralarında kötü söz söyleyip durması; çekişmek, tartışmak 2. köpeklerin havlamaları, köpeklerin birbirine ürüp durması (KTS 56).

baqılda-: kurbağaların aralarında bağrışması, "vrak vrak" diye bağırmak (KTS 56).

baqır-: bağırmak (KTS 56).

baqırawıq: 1. çok bağıran; huysuz, kavgacı 2. hiç durmadan bağıran hayvan (genellikle deve veya sığır) (KTS 56). barq et-: 1. coşmak, gayret etmek, çırpınmak 2. çirkin sesle bağırmak, haykırmak (KTS 62).

barqılda-: hangi söz olursa olsun yerli yersiz onu söylemek, gevezelik edip durmak (KTS 62).

barqıra-: sert ve yüksek sesle bağırmak, haykırmak (KTS 62).

barqırawıq: bk. baqırawıq.

bezilde-: 1. bağırmak, mızır mızır ses çıkarmak 2. Yaranın sızlaması, zonklamak (KTS 82).

bıdırla-: hızlı hızlı konuşmak; kötü kötü konuşmak (KTS 82).

bıj-bıj: yağ ve sıvıların çıkardığı ses (KTS 83).

bıjılda-: çok konuşmak, söylenmek (KTS 83).

bıjıq: çok konuşan, geveze (KTS 82).

bıj-şıj: 1. yağ dökülerek yapılan hafif ve kolay yiyecek 2. perişan, dağınık, savruk dökük (KTS 83).

bılgạla-: eğilmek, bükülmek, dönmek, döndürmek, sallamak (KTS 83).

bıljıra-: sözü anlaşılmaz bir şekilde söylemek, yarım yamalak ve patır kütür konuşmak (KTS 84).

bılpılda-: köpürerek konuşmak; yüksekten atmak, övünerek söylemek (KTS 84).

bılq-bılq et-: hâlsizleşmek, güçsüzleşmek, gevşemek, yumuşamak (KTS 84).

bılqılda-: yumuşamak, gevşemek (KTS 84).

bılş et-: yumuşak bir şeyden vurma/çarpma/düşme sonucu çıkan ses, ses çıkmak (KTS 84).

bılş etpe-: utanmamak, çekinmemek, sakınmamak (KTS 84).

bırq-bırq et-: 1 . yemeğin ses çıkararak kaynaması, fokurdamak 2. çocukların büyük abdestini bozması (KTS 84).

bırqılda-: 1. yemeğin kaynamas1, fokurdamak 2. büyük abdest bozmak; yellenmek (KTS 84).

bırqıra-: kazandaki yemeğin koyu kıvama gelip kaynaması, fokurdamak (KTS 84).

bıt-şıt: bk. pıt-şıt (KTS 85).

buldır: açık ve net olmayan, belirsiz; karanlık, bulanık (KTS 102).

buldıra-: 1. hayal meyal görünmek, zor görünmek, belli belirsiz görünmek 2. bulanmak, kararmak (KTS 102).

bulq1-: çırpınmak, hareket etmek (KTS 103). 
bulqın-: çırpınmak, hareket etmek, sallanmak, hamle yapmak (KTS 103).

bultanla-: sallanmak, sarsilmak (KTS 103).

burq: dökülmeyi akmayı anlatan ses taklidi (KTS 105).

dabır-dübir: tapır tıpır ses (KTS 113).

dabırla-: yüksek sesle konuşmak (KTS 113).

dayğıl: ses, bağırış, gürültü (KTS 114).

dāğırla-: içi boş metal nesnelerin bir yere vurulduğunda çıkardıkları ses, tınlamak (KTS 114).

darılda-: 1. sert ve yüksek sesle konuşmak 2. genellikle ağır makine ve motorların ses çıkarması, harıldamak (KTS 114).

darqılda-: 1. çok konuşmak, gevezelik etmek 2. övünmek, böbürlenmek (KTS 114).

dı̄ğır: metalden yapılmış bir şeyin başla bir şeye temasından çıkan ses, tıngır, tıngırtı (KTS 122).

dırılda-: çalışan alet, motor vb. ses çıkarmak (KTS 122).

dızılda-: vizırdamak, vizıldamak (KTS 122).

digirle-: 1. yakalanan balığın oynaması, hareket etmesi, çırpınması 2. yavaş veya fisıldayarak konuşarak birinin tadını kaçırmak 3. bir şeyin düz olmayan bir yerde tıkırdaması, ses çıkarması (KTS 122).

dikilde-: yüreğin sık sık ve güçlü atması, yüreği güp güp atmak (KTS 122).

dingirle-: 1 . bir şeyin peşi sıra konuşup durmak 2. sık s1k veya tekrar tekrar gelmek (KTS 123).

dịkilde-: 1. ayağını hızlı hızlı ve sert basarak yürümek 2. bir şeyin peşinden dingil dingil gelmek (KTS 123).

dirilde-: 1. soğuktan titremek 2. bir şeyden korkup titremek (KTS 123).

duw: bağırtı, gürültü, yüksek ses (KTS 127).

dübir: yürüyen insan veya hayvanların ayaklarından çıkan ses (KTS 128).

dük-: 1. bir şeye vurmak, 2. kaktırmak, ittirmek (KTS 122).

dükilde-: takırdamak, tıkırdamak (KTS 128).

dümpilde-: 1. gürp gürp etmek, düm düm diye ses çıkarmak 2. bir haberin söylentinin yayılması (KTS 128).

düpirle-: 1. güpürdemek, gümbürdemek 2. Bir şeyin üst üste gelmesi, gümbür gümbür gelmesi (KTS 129).

dür dür et-: bir şeyin silkindiğini ifade eden silkinme sesi (KTS 129). dürilde-: "dür dür” diye ses çıkarmak, pır diye uçmak (kuşlar için) Ör: dürildesip uşqanday qus "pır pır ederek uçunca kuş" (KTS 129).

dürs-dürs: 1 . at ayağının veya ona benzer şeylerin sesi 2. yürek çarpıntısının sesi (KTS 129).

düsirle-: düsir düsir ses çıkarmak (KTS 130).

elp et-: 1. birden görünme, aniden görünüp yok olma 2 . hareket ve kımıldanmayı ifade eder (KTS 134).

enkilde-: ağlamak, hıçkırarak veya inleyerek ağlamak (KTS 137).

gibirtikle-: 1. küçük adımlarla hızlı hızlı yürümek 2 . sabırsızlanmak, bir şeye karşı dayanamamak (KTS 169).

gilkilde-: koyu sıvılı yiyeceklerin titremesi, dirildemek; jürek gilkilde-: yüreği titremek, korkmak (KTS 170).

gilt et-: 1. öfkelenmek, kızmak 2. kırılma, burkulma gibi hareketlerde ses çıkması, çıt etmek, küt etmek (KTS 170). guwla-: çınlamak, bir sesin kulakta çınlaması (KTS 184).

gübir-gübir: 1. ancak işitilecek kadar insanların konuşması, fisır fisır 2. kendi kendine konuşma, fisıldama, fisıltı (KTS 173).

güm bol-: 1. sesi çıkmamak 2. yok olmak, kaybolmak (KTS 174).

gümbirle-: 1. gümbürdemek 2. ev, bina vb. ağır şeylerin yıkılırken ses çıkarması 3. çalınan sazın ses çıkarması 4. topun ses çıkarması (KTS 174).

gümpilde-: 1. gümbürdemek 2. boşa övünmek, boş konuşmak (KTS 175).

güjiren-: yarılan, kırılan bir şeyin ses çıkarması (KTS 175).

gü円kilde-: bir şeyi anlaşılmaz şekilde mırıldanmak, anlaşılmayacak şekilde konuşmak (KTS 175).

gürkire-: gürüldemek, gürlemek, gök gürlemek (KTS 176).

gürsilde-: 1. yıkılan, devrilen ağır nesnelerin ses çıkarması, gürüldemek 2. inildemek (KTS 176).

güwilde-: uzun süre çınlayarak/vınlayarak çıkan sesin işitilmesi, vınlamak, uğuldamak, çınlamak (KTS 176).

güwle-: gürlemek, hızla geçip gitmek, güw diye ses çıkarmak (KTS 177).

güybenle-: bir yerde oraya buraya sallanarak yürümek, dönmek, sallanmak (KTS 177).

ğağırla-: kurumuş derinin ya da deriden yapılmış yapılmış şeyin dokunulduğunda veya giyildiğinde ses çıkarması, gacur gucur etmesi (KTS 179). 
ğanğırla-: metalin bir şeye çarptığında çıkardığı ses, tınlamak (KTS 180).

ğanqılda-: kazın başka kazları çağırırken ses çıkarması, gaglamak. Ğarğa ğanqıldap ğaz bolmas "karga kaz gibi gaklayamaz, karga gaklamakla kaz olmaz” (KTS 180).

ğaqaqla-: yumurtlayacak olan tavuğun gidaklaması (KTS 179).

ğarq: 1. ördek sesi 2. kahkaha sesi, aşırı gülmeden çıkan ses (KTS 180).

ğarqılda-: 1. gaklamak 2. yüksek sesle, kahkahayla gülmek (KTS 180).

ğawqılda-: yerli yersiz yüksek sesle konuşmak (KTS 181).

ğıj ğıj et-: söylediği veya düşündüğü olmayıp içi öfkeyle/ sikıntıyla dolmak (KTS 182).

ğırşılda-: karda yürürken ayaktan ses çıkması, gıcırdamak (KTS 183).

ğışırlat-: dişlerini gıcırdatmak (KTS 183).

ğıyqılda-: Boğazından sıkıp hırıldatmak (KTS 183).

ğıyt: genellikle "1lak" oyununda at koştururken kullanılan ses, nara (KTS 122).

ğuj ğuj: çok fazla, ziyade, yoğun (KTS 183).

ıbır-sıbır: dedikodu, fisıltı (KTS 201).

ıljıra-: yumuşamak, gevşemek, boşanmak (KTS 203).

ıłılda-: yavaş ses çıkarmak, inildemek (KTS 204).

ıjıran-: inlemek, inildemek (KTS 204).

ıj-jı): bağırma, gürültü, patırtı (KTS 204).

ıqqlda-: inlemek, inildemek; yorulmak (KTS 204).

ınq-ınq et-: inildemek (KTS 204).

Irılda-: 1. köpeğin vb.nin hırlaması 2. insanların çok konuşup durması, karşı çıkması. İttey ırıldawıs "it gibi hırıldaşmak" (KTS 205).

ırjıy-: sırıtmak, bıyık altından gülmek (KTS 205).

ırjıyt-: sırıtmak, dişini göstermek. Maşınlar tisin ırjıytıp / birin-biri sürip ketti “Arabalar dişini gösterip birbirini sürüyip gitti” (KTS 205).

Irsılda-: yorulmak, bitap düşmek (KTS 205).

Isılda-: 1 . "1s 1s" diye ses çıkarmak fisıldamak 2. Ok vb. şeyler havada ses çıkarmak, 1slık çalmak (KTS 206).

IZ Iz et-: 1zıldamak (KTS 207).

ızılda-: vızıldamak (KTS 208).
Izıy: vızıldayan ses, vızırtı. Izın 1zın söz "belli belirsiz söz"; 1zı̣ ızı̣ suwıq: ses çıkararak esen soğuk rüzgâr (KTS 208).

ingäla-: bebek ağlarken ses çıkarmak, ınga ınga demek (KTS 213).

jabırla-: herkes her ağızdan konuşmak, her taraftan konuşmak (KTS 219).

jalbıra-: yırtılmış elbise vb. şeyin sallanıp durması, yırtığın sallanması (KTS 222).

jalp et-: 1. çocukların koşması, koşmak 2. at ve eşekle koşturmak (KTS 223).

jalt et-: hareketin çabucak ortaya çıkışı, birden bire olmak (KTS 224).

jaltan bol-: korkmak, çekinmek. Türli jolğa jaltan etip jasatıp. "Türlü yola sevk ederek yaşatıp" (KTS 225).

jaltılda-: parlamak, bir görünüp bir kaybolacak şekilde 1şık saçmak (KTS 224).

jaltır: parlak, parlayan (KTS 224).

jaltıra-: parlamak, 1ş1ldamak; 1şıkta görünmek (KTS 224).

jarq et-: birden parlamak, 1şık saçmak (KTS 229).

jarqıra--: 1şık saçmak, parlamak. Jarqıratıp appaq jüzin / jawdıratıp eki közin "aydınlatıp ak yüzünü / parıldatıp iki gözünü” (KTS 229).

jelkildes-: sallanmak, dalgalanmak, oynamak. Jaslar jelkildesip, jüzleri jaynap. "Gençler sallanıp yüzleri güler" (KTS 238).

jelpilde-: 1. bir inip bir çıkmak 2. çıkmak, görünmek, ortaya çıkmak (KTS 238).

jıbır-jıbır et-: kımıldamak, kıpırdamak, hareket etmek (KTS 241).

jığırla-: kuşlar için bir yere toplanıp ötüşmek, cıvıldamak (KTS 241).

jılp-jılp et-: hızlı ve çevik hareket etmek (KTS 242).

jıltılda-: bir sönüp bir yanmak, yanıp sönmek (KTS 243).

jıltır: parlak, 1şıl ışıl (KTS 243).

jım bol-: hiç ses çıkarmamak, konuşmamak, suspus olmak (KTS 243).

jımpılda-: bir şeyi çabucak ve kolayca yapmak (KTS 243). jı̈q etpe-: seslenmemek, karşılık vermemek (KTS 243). jırqılda-: kuş ötüşmesi, cıvıldamak (KTS 243).

juğırla-: 1. yemeğin fokurdayarak kaynaması 2. kuşların bir yere toplanıp ötüşmesi 3. çocukların bir araya gelerek bağıra çağıra oynaması (KTS 250). 
julqıla-: tekrar tekrar silkelemek, çekmek, çekiştirmek (KTS 250).

juwdırla-: şıkırdamak, şakırdamak, cıngırdamak (KTS 224).

kekir-: geğirmek (KTS 261).

keøkilde-: ağlarken veya gülerken kesik kesik ses çıkarmak, kıkırdamak (KTS 266).

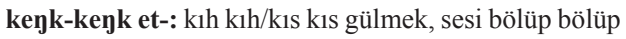
gülmek (KTS 266).

kisne-: at kişnemesi, kişnemek (KTS 275).

kiş-kişle-: 1 . bir şeyi (hayvan vb.) önüne alıp ağzından ses çıkararak sürüp götürmek, gütmek, kişkişlemek 2 . dürtmek (KTS 275).

qalş-qalş et-: aşırı korkudan, soğuktan veya acıdan tir tir titremek (KTS 312).

qalt qalt et-: bir o yana bir bu yana çalkalanmak, bir sağa bir sola sallanmak (KTS 313).

qaltılda-: 1. titremek, çok üşümek 2. yavaşça ürkerek yürümek (KTS 313).

qanğırla-: bk. ğanğırla- (KTS 317).

qaysı-: 1. kokmak, bozulmak, ekşimek 2. köpeğin acı acı bağırması, acıyla ulumak (KTS 318).

qaqılda-: gereksiz, nahoş sözleri çok söylemek (KTS 308).

qaqır-: tükürmek, tükürük çıkarmak, balgam atmak (KTS 308).

qılmııla-: gülümsemek, tebessüm etmek (KTS 340).

qılqılda-: bir sıvıyı ses çıkararak içmek (KTS 340).

qIltınla-:nazla, eda ile yürümek, cilveli olmak (KTS 340).

qırılda-: hırıldamak (KTS 342).

qırşıl-: yarılmak, sıyrılmak, yaranın kabuğunun kalkması (KTS 343).

qurtılda-: sert bir nesnenin "kırt" diye ses çıkarması, kıtırdamak, kütürdemek (KTS 243).

qıtıqla-: 1. gıdıklamak 2. kıpırdatmak, hareketlendirmek (KTS 344).

q1yğır-: bağırmak (KTS 345).

q1yqıwla-: bağırmak; hep birden ses çıkarmak (KTS 346).

qorılda-/qurılda-: uyurken horuldamak (KTS 361).

qorqılda-: sıv1 nesneyi höpürdeterek içmek 2. Ses çıkarmak (KTS 353).

lap et-: bir şeyin birden bire yanması (KTS 368). laq et-: kaptaki suyun birdenbire devrilip dökülmesi (KTS 367).

laqılda-: 1. sıvı nesnelerin fişkırarak çıkması 2. sıvının fokur fokur kaynaması 3. kahkahayla gülmek, kahkaha atmak (KTS 367).

larqılda-: yüksek sesle gülmek, kahkaha atmak (KTS 368).

larsılda-: 1. Soğuk algınlığından dolayı öksürmek 2. Sesli gülmek, yüksek sesle gülmek 3. Yere yıkılmak, küt diye düşmek (KTS 369).

lıp et-: 1 . bir şeyin birdenbire görünmesi, aniden ortaya çıkmak 2. bir şeyin birden bire yok olması, sönmesi (KTS 373).

lıqılda-: 1. sıvının ses çıkararak dökülmesi 2. bir kabın herhangi bir şeyle dolması (KTS 372).

lıq-lıq: hıçkırık (KTS 372).

lüp et-: yüreği atmak, yüreği güm güm çarpmak (KTS 375).

malpılda-: hareketi/yürüyüşü yavaş, hâlsiz yürümek, sallana sallana yürümek (KTS 379).

manqıldaq: geveze, ileri geri konuşan, patavatsız (KTS 380).

mayıra-: koyun, keçi, sığır gibi hayvanların bağırması (KTS 380).

mıj-mıj et-: bir sözü tekrar tekrar söylemek (KTS 393). mıljııla-: sık sık anlamsız şeyler söylemek (KTS 394).

mı引ğırla-: bir şeyi düşünmeden, anlamsızca söylemek, mirıldanmak (KTS 394).

mınq etpe-: hareket etmemek, kımıldamamak (KTS 394). mııqılda-: burnundan konuşmak, anlamsız konuşmak (KTS 394).

mırılda-: mırıldamak, kedilerin mırıldaması (KTS 395).

mırjıq: yüzeyi kırışmış, buruşuk (KTS 395).

mırjıy-: gülümsemek, tebessüm etmek (KTS 395).

mırs mırs etip kül-: kıs kıs gülmek, hafifçe ve zor duyulur tarzda gülmek (KTS 395).

mıyaw: kedi sesi "miyav" sesi (KTS 395).

möyire-: hayvanların böğürmesi (KTS 403).

münkilde-: kötü koku çıkmak, burna kötü koku yaymak (KTS 407).

ökir-: bağırmak, yüksek sesle ağlamak. Ögizdey ökir-: öküz gibi bögürmek, çok bağırmak (KTS 438). 
ökireyle-: yersiz hareket etmek, kaba davranmak; bozgunculuk yapmak (KTS 438).

payq et-: 1. sert ve gür ses çıkmak 2. tam ortasından ayrılmak, yarılmak 3. övünmek (KTS 451).

parılda-: "pat” diye ses çıkarmak, patırdamak (KTS 453).

partılda-: sesin patırdayarak gümbürdeyerek çıkması (KTS 455).

partla-: 1. patlayarak ses çıkarmak, yarılmak 2 . kaynatmak, kaynatıp temizlemek (KTS 455).

patırlan-: 1. "patır” diye ses çıkarmak 2. sert konuşmak, bağırarak çabuk çabuk konuşmak (KTS 457).

pırılda-: 1 . horuldamak 2. pır diye uçmak, kanat çırpıp havalanmak (KTS 464).

pırla-: 1. "pır" diye ses çıkarmak 2. hızla koşmak, uçarcasına koşmak (KTS 464).

pırqılda-: "pırq pırq" diye ses çıkarmak (KTS 464).

pırrım-pırrım bol-: ayrı ayrı, parça parça olmak (KTS 464).

pırt et-: sıvının/suyun birdenbire sıçraması, fişkırması (KTS 464).

pırt-şırt deme-: ses çıkarmamak, konuşup münakaşaya sebep olmamak (KTS 464).

pıs et-: yellenmek (KTS 464).

pısqır-: 1 . burnundan şiddetli ses çıkarmak, hırıldamak 2. püskürmek, fışkırmak 3. kibirlenmek, böbürlenmek (KTS 464).

pışılda-: fışırdamak, "fışır" diye ses çıkarmak (KTS 465).

pışırla-: çıtırdamak, hışırdamak (KTS 465).

pıtırla-: çıtırdamak (KTS 465).

pıt-şıt bol-: parçalanmak, bölünmek, dağılmak (KTS 465).

saldırla-: birbirine dokunarak ses çıkarmak (KTS 487).

salpılda-: 1. sallanmak 2. avare olmak, başıboş ve faydasız dolaşmak 3. yersiz ve anlamsız konuşmak (KTS 488)

sampılda-: bağırmak, uygunsuz ve sert konuşmak (KTS 485).

sandıraq: 1. hasta kişinin yersiz ve anlamsız sözleri 2 . saçma söz, yakışıksız söz (KTS 489).

sayğır et-: "şangır” diye ses çıkarmak, şangırdamak. Tasqa tüsken şölmektey şayğır etip... "Taşa düşen çömlek gibi şangırdayıp..” (KTS 490).

sayqılda-: yüksek sesle konuşmak veya ses çıkarmak, gürlemek (KTS 490). saqılda-: titremek, zangırdamak (KTS 485).

saqırla-: fokurdamak (su vb.) (KTS 485).

sarqıra-: Suyun çağlayarak akması, çağlamak (KTS 491).

sart et-: iki şeyin birbirine dokunması sonucu "sart" diye ses çıkarmak (KTS 492).

satır-satır: "çatır çutur” tarzı çıkan ses. Qaşıp duşpan satır satır / Şähärine tığılğan eken. "Kaçıp düşman çatur çutur, şehrine tıkılmış imiş” (KTS 492).

selk et-: sıçramak, birdenbire irkilmek (KTS 499).

selkilde-: titremek, kımıldamak, sarsılmak (KTS 499).

seltegle-: dikkatle bakmak (KTS 500).

sibırla-: fisıldamak (KTS 502).

sılbır: gevşek, boş; yeteneksiz, sakar (KTS 503).

sıldır: herhangi bir şeyin çıkardığı ses, şırıltı, şıngırtı vb. (KTS 503).

sıldırla-: hışırtı, çıtırtı çıkarmak (KTS 503).

sılpılda-: sılp sılp ses çıkarmak (KTS 503).

sılq et-: birden düşmek, boşalıp düşmek (KTS 503).

sılt et-: kımıldamak, hareket etmek (KTS 503).

sınq et-: sesli olarak ağlamak, hıçkırarak ağlamak veya sesli gülmek (KTS 504).

sınğırla-: dokunma sesi, temas sonucu çıkan ses (KTS 504).

sıpsın: dedikodu, yalan söz (KTS 505).

sıqırla-: şıkırdamak (KTS 503).

sırılda-: hirıldamak (KTS 505).

sırqıra-: suyun ses çıkararak akması, şırıldamak (KTS 505).

sırt et-: "sırt" diye ses çıkarmak (KTS 506).

silkin-: 1. irkilmek, sıçramak 2. birdenbire havalanmak, kanat çırpmak (kuş için). (KTS 508).

simgir-: burnun pisliğini temizlemek, sümkürmek (KTS 508).

solqılda-: 1 . boşluğu olmak, gevşek olmak 2. titremek, sarsilmak 3. zonklamak (KTS 511).

şaqalaq at-: kahkaha atmak (KTS 525).

şalp et-: suyun "şalp" diye ses çıkarması (KTS 528).

şalpılda-: dalganın kıyıya vurup ses çıkarması; çalkalanmak (KTS 528).

şambırla-: sıvıdan, sudan çıkan ses, şapırdamak, şıpırdamak (KTS 528). 
şaqaq: kahkaha. Awıldın balların jıynap / şaqaq urğan şul künlerim "Köyün çocuklarını toplayıp / kahkaha attığım o günlerim” (KTS 525).

şaqılda-: şakırdamak, tıkırdamak (KTS 525)

şaqır-: 1. uzakta bulunan bir kimseyi ses veya işaret ile çağırmak 2. davet etmek (KTS 525).

şaqırawıq: çok ses çıkaran; bağırgan (KTS 525).

şaqırla-: şakırdamak, şıkırdamak (KTS 525).

şapalakla-: 1. iki elin avucunu birbirine vurmak, şaplak çalmak, alkışlamak 2. şaplak ile vurmak, tokatlamak (KTS 530).

şarpılda-: bir şeyin ikinci bir şeye değmesi/dokunması (KTS 532).

şartılda-: bir şeyin "şart (çat)." diye ses çıkarması, çatırdamak (KTS 532).

şatır-şatır: çatır çutur (KTS 533).

şıjılda-: kaynayarak ses çıkarmak, fokurdamak, cızırdamak (KTS 541).

şıldır qaq-: demir vb. şeylerin birbirine değmesi sonucu çıkan ses, şıkırtı çıkmak, zil çalmak (KTS 541).

şılqılda-: bir şeyin su vb. sıvı ile dolması (KTS 541).

şımbırla-: sıvının köpük çıkararak hareket etmesi, çalkalanmak (KTS 542)..

şıqılda-: çağıldamak, şıkırdamak vb. ses çıkarmak (KTS 541).

şırpılda-: 1. hızlanmak, çabuk çabuk hareket etmek 2. ses çıkarmak, vurmak çalmak. Şırp şırp et-: hızlanmak (KTS 544).

şırt et-: 1. öfkelenmek, kızmak 2. çıt diye kırılmak (KTS 544).

şıtırlaq: çıtırdayan, çıtırdak (KTS 544).

şıykıldağıș: cıvıldayan; gıcırdayan (KTS 545).

şingirle-: 1. sözü tekrar tekrar söylemek 2. atın kişnemesi, kişnemek (KTS 546).

şinkilde-: ince sesle konuşmak (KTS 546).

şorpıldat-: şapur şupur öpmek (KTS 549).

şorşı-: ürkmek, irkilmek (KTS 549).

şurqılda-: şırıldamak, suyun ses çıkararak akması (KTS 552).

şuwılda-: 1. bağrışmak, gürültü çıkarmak 2. çağlamak "şuv" diye ses çıkarmak (KTS 553).

şüykilde-: civciv veya kuş yavrularının bir yere toplanması (KTS 554). täkir-tükir et-: takır tukur etmek, takır tukur ses çıkarmak (KTS 573)

talpın-: 1. çocuğun yürümeye gayret etmesi, yürümeye çalışması 2. bir amaca ulaşmak için gayret etmek, çabalamak (KTS 561).

tanqılda-: bağırarak ve sert konuşmak (KTS 564).

taqılda-: 1. "tak tak" ses çıkarmak 2. açık açık konuşmak (KTS 559).

taqır-tuqır: takır-tukur şeklindeki ses (KTS 559).

tarbạ: yavaş yürüyüş, aheste gidiş (KTS 566).

tars et-: sesin yüksek, güçlü çıkması (KTS 567).

tasır: atın ayak sesi veya benzeri ses (KTS 568).

tasır-tusur: tars turs eden yüksek ses, takırtı sesi (KTS 568).

tıpırla-: bir yerde duramayıp ayaklarını kıpırdatmak veya yere vurmak (KTS 585).

tıqılda-: 1. tıkırdamak 2. çocukların hızlı hızlı konuşması (KTS 583).

tırpılda-: ayağını yere vurarak (ses çıkararak) yürümek, ayaklarıyla yere vurarak ses çıkartmak (KTS 586).

tırsılda-: tıkırdamak, takırdamak, hışırdamak (KTS 586). tırtıyla-: yaralamak, tırmalamak; boşuna çabalamak, yırtınmak (KTS 586).

tompayla-: yeni yürümeye başlayan çocuğun hızlı hızlı ve düşecek gibi yürümesi (KTS 595).

tompılda-: "pat pat” diye ses çıkarıp düşmek (KTS 595). tonqılda-: söylenmek, mızırdanmak, huysuzluk etmek (KTS 596).

toqılda-: takırdamak “tak” diye ses çıkarmak (KTS 592). tükirik/tüpirik: tükürük (KTS 609-610).

ulı-: ulumak (it, kurt). (KTS 620).

ulı-qıyqıw sal-: bağırmak (KTS 620).

uwdır-juwdır: gürültü, patırtı; dın dın; zınk zınk (KTS 626).

uwıldı-şuwıldı: her türlü ses, uğultu (KTS 627).

uypa-juypa: düzensiz, karmakarışık (KTS 629).

wajılda-: her türlü ses çıkarmak, kaynayıp fokurdamak (KTS 641).

wayqılda-: inlemeli ses çıkarmak, acı ses çıkarmak (KTS 641)

warqılda-: kahkahayla gülmek, bağırmak (KTS 642).

way-wayla-: ağlamak, bağırmak; vay vay çekmek; haykırmak (KTS 642). 
zaqılda-: bir sözü tekrar tekrar söylemek; ses yüksek sesle çıkmak (KTS 649).

zım-: birden geçip gitmek, hızla geçmek (KTS 652).

zınqılda-: çabuk gitmek, hızlı hareket etmek (KTS 652).

zıy: 1. koşmak, hızla gitmek 2. firlatıp atmak (KTS 652).

zıyla-: bir şeyin hafifçe ses çıkarması (KTS 652).

zır zır aynal-: hızla dönmek, çabuk çabuk dönmek (KTS 652).

zırılda-: çabuk gitmek, hızlı hareket etmek (KTS 652). zırq-: hareket etmek, kımıldamak, akmak, sızmak (KTS 652). zırqılda-: zonklamak, sızlamak, ağrımak (KTS 652).

zırrıkla-: ötürmek, ishal olmak (KTS 652).

zinkildek: 1. hızlı hızlı yürümek 2. sık sık gitmek; sık sık gidip rahatsız etmek, tadını kaçırmak (KTS 653).

zirilde-: 1. donmak, soğuktan titremek 2. bir şeyden çok korkmak, yüreği titremek (KTS 653).

zonq et-: birden çıkmak görünmek (KTS 653).

zuwılda-: vınlamak, hızla geçip gitmek (KTS 654). 
